\title{
Markers for Global Climate Change and Its Impact on Social, Biological and Ecological Systems: A Review
}

\author{
Ravi Kant Upadhyay \\ Department of Zoology, D. D. U. Gorakhpur University, Gorakhpur, India \\ Email: rkupadhya@yahoo.com
}

How to cite this paper: Upadhyay, R. K. (2020). Markers for Global Climate Change and Its Impact on Social, Biological and Ecological Systems: A Review. American Journal of Climate Change, 9, 159-203. https://doi.org/10.4236/ajcc.2020.93012

Received: May 6, 2020

Accepted: August 16, 2020

Published: August 19, 2020

Copyright $\odot 2020$ by author(s) and Scientific Research Publishing Inc. This work is licensed under the Creative Commons Attribution International License (CC BY 4.0).

http://creativecommons.org/licenses/by/4.0/

\begin{abstract}
Present article sketches out major climate induced changes in marine, aquatic and terrestrial life. Few important biomarkers such as ecological, meteorological, socioeconomic, thermal, biophysical and biological, behavioral markers of climate change and global environmental stress have been highlighted to predict the future challenges and finding appropriate solutions. Though, so many climate change induced effects are visible but few unpredictable effects may be seen in future. Therefore, all such effects have been acknowledged, and tried to find appropriate solutions. Most visible effect is collection of high amounts of carbon dioxide in the atmosphere which is responsible for green house effect and causing natural calamities round the globe. It is not only jeopardized the survival of terrestrial, fresh water animals mainly planktons, bottom dwellers; coral reefs, algae, fish fauna in marine environment belong to different taxon but also responsible for disruption of ocean's food web due to non-assimilation of extra carbon dioxide by the ocean water. There is a sharp decline in fresh water and sea shore micro-flora and micro-fauna. Other major visible effects are loss of biodiversity, depletion of forests, land degradation, severe floods and draughts. On other hand sudden changes in weather conditions causing irreparable devastations due to hurricanes and typhoons, storms, lightening, earthquakes and tsunamis are normally on rise. Both economic and ecological breakdowns are occurring more frequently which are more impactful and persistent. Climate change is major human health stressor; it is making fragmentation of socio-cultural bonds and reducing fertility of soil finally crop production. Climate change is imposing nonadaptive forced human migration, territorial conflicts, decreasing ecosystem productivity, disease out breaks, and impelling unequal resource utilization.
\end{abstract}




\section{Keywords}

Global Climate Change, Biodiversity Loss, Loss of Life, Habitat, Economic Losses, Biomarkers, Challenges and Solutions

\section{Introduction}

Today climate change is a very serious problem as it is causing irreparable losses and damages to physical, biological environment and human life. People are facing worsening problems due to climate changes as almost every year casualties of human life, health, physical wealth, destruction of habitat and resilience are increasing due to hurricanes, blizzards, tornados, floods, draughts and earthquakes round the globe (IPCC, 2006). Climate change encompasses both increase and decrease in temperature as well as shifts in precipitation. Temperature variations are responsible for devastating floods, no rains or droughts for longer duration. It is lonely factor that is severely affecting world economy and growth. However, sudden changes in weather events disrupt human life and impose multiple risks and cause economic damages (IPCC, 2006). More vulnerable condition is prevailing in coastal areas, mountain regions, deserts, dry lands, wet-lands and humidified climatic zones (Dube et al., 2000). In arid and semi arid zones, there is a sharp rise in temperature and heat induced deaths. There is occurring a sharp increase in land degradation, soil erosion, and devastating floods which cause landslides. Heavy devastations have been observed in destruction of biodiversity of hydrophytes, pollinators, symbiotic bacteria, and coral reefs, fishes, amphibians, reptiles, mammals and invertebrates mainly insects (IPCC, 1992, 2001). Sea water warming is causing stress to corals mainly bleaching that leads to mass coral decline.

Sever alterations have been noted in temperature and water/rains/precipitation over a time period of six decades or longer. Few unthinkable changes are going on in air and ocean temperatures which have caused rise in sea level, heavy melting of snow and ice caps situated on poles. During last six decades elevation in earth temperature caused global warming and its main reason is human influence in different primary ecological divisions of earth. A 2 - 3 degree elevation in temperature imposes mutations that confer resistance to drug that may be a rare one and Climate Change (2001), Impacts, Adaptation, and Vulnerability. The average annual temperature is rising year after year round the globe. Its worst impact can be seen in coastal areas where rising sea levels, extreme weather events and prolonged drought has displaced millions of people and they are forced to live in poverty and homelessness. People are leaving these areas or habitat and migrating in search of food, water, shelter and jobs every year.

However, climate changes are increasing natural calamities that resulted in displacement of poor, destruction of their livelihood means and housing. Heavy losses were observed in transportation, information, health and food supply sys- 
tems. Devastations in mega cities, metropolitan, urban towns have been seen at global level with heavy losses to infrastructure whose functional repair never become possible. Though climatic conditions do not remain stable but their furious actions persists over decades or longer and world climate is moving in an unpredictable direction (Hulme et al., 1999). An on-going damage is occurring, not just too public infrastructure such as roads, bridges and water treatment plants, but to our entire built environment. Affected people need medical services and need quick rehabilitation and emotional management. The majority of the adverse effects of climate change are experienced by poor and low-income communities around the world.

Changing weather conditions are creating problems to soil formation, humus formation and biomass degradation due to loss of bacterial activity. Soil acts as a natural media for microbes where they fix and convert atmospheric nitrogen in to organic products, thus soil acts as a bridge between inorganic and organic and living world (Jiao et al., 2019). Soil is natural habitat of a vast array of sub-surface organisms, burrowers, and dwellers. Among other factors are anthropogenic activity and presence of grazers, water-use efficiencies, and climatic effects decrease or increase in vegetative cover (Nelson et al., 2006). Soil poisoning due to use of heavy metals, pesticides, herbicides and weedicides is a major problem. These chemicals are seriously affecting soil micro-fauna, macro-fauna and mesofauna. Besides this, a number of climatic factors, including climate, soil organisms, and their associations with other organisms is seriously in jeopardy (Nelson et al., 2006). Furthermore, regular and constant inputs of carbon to soils from vegetation, changes in temperature, low precipitation and evaporation cause significant changes in organic matter turnover from soil or productivity and $\mathrm{CO}_{2}$ assimilation (Ainsworth \& Long, 2005). However, increased productivity of soil depends on greater inputs of carbon to soil, thus increasing organics. Annual rainfall decrease or increase severely affect growth of soil microbes and soil productivity. The rain water is most associated requirement for formation of soil, soil fertility, and soil structure (Ainsworth \& Long, 2005).

\section{Adverse Effects of Global Warming}

Ecosystems maintain themselves by cycling energy and nutrients obtained from external sources. At the first trophic level, primary producers (plants, algae, and some bacteria) use solar energy to produce organic plant material through photosynthesis. At this level presence of extra $\mathrm{CO}_{2}$ in environment is responsible for all negative effects including global warming, precipitation and alteration in hydrobiological cycle (Stacey \& Fellows, 2002). Climate changes have severely affected mangrove vegetation and mountain forests (Colfer et al., 2006). Its worst effects are seen in fresh water ecosystem and marine ecosystem where both invertebrates and vertebrate fauna are dying and caused a sharp decrease in their population. Both marine and freshwater birds are large victims of harmful hydrocarbons, crude oil and atomic discharges or nuclear wastes. Increased levels 
of $\mathrm{CO}_{2}$ emissions badly affected the hydrologybiological cycles and soil structure. This elevated level of carbon is responsible for increase in global warming, and loss of biological diversity i.e. microfauna to macrofauna in major world ecosystems (Galatowitsch et al., 2009). Increased atmospheric $\mathrm{CO}_{2}$ collection has created natural climate availabilities widely influencing plant animal interactions (Hulme et al., 1999; Ehleringer et al., 2002). Besides this, heavy metal toxicity in soil and $\mathrm{SO}_{2}$ in atmosphere are creating problem to photosynthesis.

All climate induced vulnerabilities are causing detrimental effects on human health and ecosystems. Overall effects and impact of climate change on human health must be evaluated by considering current reports with the future implications for existing risk-assessment and management. In present article efforts have been made to search different types of markers i.e. mainly clinical ecological, meteorological, demographic, pathogenic, deforestation, socio-cultural and socioeconomic, political, thermal, biophysical and biological biomarkers economic which could help in finding solutions to climate change. Ecological markers are land degradation, denudation and defoliation in temperate climatic zones. Climate-induced effects are visualized in form of loss of biodiversity mainly key stone plant species and associating flora that leads to changes in physiographic and agro-ecosystems. Climate is severely causing loss of symbionts and pollinators, thereby breaking ecological interconnections, results in low crop yield. Thus diminishing food availability are creating problems to ecological behavior in reproductive animals. More attention has been given on biological markers mainly seasonal variations on endocrine homeostasis, disturbance in circadian rhythms, migration, survivorship, natural selection, animal development and parental care.

There are different markers of climate change i.e. demographic fragmentation of socio-cultural bonds, forced and non adaptive migration, loss of agriculture production in tropics, unemployment, poverty and hunger (Figure 2). There is a direct interaction between climate change and global economic growth, as the steeps in economy are seen in under-developed world which is surviving on subsidies and loans. Climatic changes are non alarming risks, majority of accidental events are making heavy losses to community property and human life. However, the top most duty of man is to mitigate adversities caused by climate. There should be an inclusive development, community cooperation, schooling, awareness, policies, practices, technological development, genetically safe crops, recyclable materials, green energy, forestation, and full efforts be made to safeguard ocean habitats include the creation of gigantic marine sanctuaries. For an improvement in cleanliness federal governments must invest more and more in infrastructure development, technological up gradation for improving sewer system and assure clean drinking water supply.

\section{Eco-Climatic Markers}

\subsection{Sharp Rise in Temperature and Heat Induced Deaths}

Biological systems are also being affected by increasing temperatures, which in- 
troduce changes in biophysical conditions that influence their development and maintenance. Temperature changes severely affect metabolism, reproduction, development, sex ratio, growth, crossing over and animal survival, development of eggs, larvae, pupae, maturation of ova and sperms, molting and other various activities. Optimum range of temperature is tolerable to plants and animals. Due to increase in surface water temperature diversity of both fauna and flora is highly affected. Low rain or no rains are also result of increase in temperature and cause disruption of hydrobiological cycle that is causing mass mortality of aquatic animals. Many freshwater species are under serious threat of extinction as a result of rising salinity, temperatures, and sharp decrease of rains and low streaming of river water (Willetts et al., 2010). Due to climate change both cloud formation and rains have been decreased, it resulted in shortage of water in water bodies and aquifers. A sharp decrease in rainfall has resulted in disappearance of water bodies such as ponds, lakes, wetlands and coastal lagoons that also causing biodiversity loss (Willetts et al., 2010).

Further, snow and ice are melting in mountainous areas at alarming rates and severely affecting mountain ecosystems (Bässler et al., 2010). The extent of snow cover in the Northern Hemisphere has decreased by about 10 percent since the late 1960s and 1970s (Parry et al., 2007a, 2007b) and mountain vegetation zones are recorded to have shifted upwards. To fight against climatic changes both plants and animals have gained adaptations but most of them are susceptible (Hanson, 2007). Increased temperatures affected physical systems, that caused extreme ice melting and snow cover is reduced, it is affecting biological systems through a series of direct and indirect factors (Table 1). Physical systems include deep snow; glaciers and permafrost in mountain region maintain low temperature. It also assists in formation of tree line and snow line (Figure 2).

The water cycle and hydrological systems are affected by changing temperatures, often indicated by dry riverbeds or floods due to increased runoff (Smith et al., 2000). In semi-desert areas, the decreased availability of water is already placing additional pressures on wildlife, which aggregate around limited water points and compete with domestic livestock (de Leew et al., 2001). Water availability affects the flowering and survival of aquatic plant species, as well as the abundance of wildlife species in affected areas. Shifting seasonal changes, in most of the temperate regions, affect the timing of animal migrations and the flowering of plants. It is affecting diurnal as well as night cycle in animals, and destabilizing the equilibrium of circadian rhythms (biological systems) and ecosystems. One large potential ecological impact of such changes is mistiming, where, for instance, migrating animals arrive at times when their necessary food plants or animals are not available (Figure 2) (Visser \& Both, 2005).

Increase in global temperature causing excess melting of ice caps and glaciers, raising sea levels and flooding estuaries. Rising sea levels are affecting coastal areas through shoreline erosion, the loss of coastal wetlands and modification of coastal vegetation. Most affected animals are coral reefs which need a minimum 
Table 1. Important biomarkers of global climate change, survival and adaptability limits.

\begin{tabular}{|c|c|c|c|c|}
\hline Climate ind & duced visible effects & Short term effects & Long term effects & Possible solution \\
\hline \multicolumn{5}{|c|}{ Ecological biomarkers } \\
\hline \multirow[t]{2}{*}{$\begin{array}{l}\text { Mountain } \\
\text { ecology }\end{array}$} & $\begin{array}{l}\text { Polar caps quickly losing } \\
\text { ice. De-glaciations }\end{array}$ & $\begin{array}{l}\text { Avalanche, landslides, Shifting of } \\
\text { timber line, species loss }\end{array}$ & $\begin{array}{l}\text { Disappearance of glaciers, } \\
\text { untimely floods, change } \\
\text { in water cycle }\end{array}$ & $\begin{array}{l}\text { Restoration of mountain forests } \\
\text { and vegetation }\end{array}$ \\
\hline & $\begin{array}{l}\text { Increased rate of ice } \\
\text { melting, stronger storms }\end{array}$ & Severe frosting, accidental floods & $\begin{array}{l}\text { Loss of alpine vegetation, } \\
\text { land slides }\end{array}$ & Reduction in global heat, \\
\hline \multirow[t]{2}{*}{ Forest ecology } & $\begin{array}{l}\text { Extra } \mathrm{CO}_{2} \text { in atmosphere, } \\
\text { Global warming }\end{array}$ & $\begin{array}{l}\text { Increase in permafrost, } \\
\text { precipitation, decrease in annual } \\
\text { rainfall, unseasonal or early } \\
\text { flooding. }\end{array}$ & $\begin{array}{c}\text { Forest fires, inundation, species } \\
\text { loss, unstable ground conditions } \\
\text { reduced bearing capacity, risk of } \\
\text { subsidence, }\end{array}$ & $\begin{array}{l}\text { Heavy re-forestation, conservation } \\
\text { of evergreen forests, protection of } \\
\text { wild life and biodiversity research }\end{array}$ \\
\hline & $\begin{array}{l}\text { Forest loss seaward, } \\
\text { migration landward, loss } \\
\text { of salt marsh and salt } \\
\text { flats }\end{array}$ & $\begin{array}{l}\text { UVB radiation Morphology, } \\
\text { productivity, recruitment, Few } \\
\text { major effects. salinity, humidity, } \\
\text { nutrients }\end{array}$ & $\begin{array}{l}\text { Enhanced } \mathrm{CO}_{2} \text {, depression of } \\
\text { night temperature, humidity loss, } \\
\text { low photosynthesis, high } \\
\text { respiration, productivity and } \\
\text { species loss }\end{array}$ & $\begin{array}{l}\text { Cut down fossil fuel reduction in } \\
\text { green house gases by replacing } \\
\text { fuels, production of green energy }\end{array}$ \\
\hline $\begin{array}{l}\text { Grassland } \\
\text { ecology }\end{array}$ & $\begin{array}{l}\text { Increase in temperature } \\
\text { Permanently frozen soil, } \\
\text { energy cycles and } \\
\text { ecosystem productivity }\end{array}$ & $\begin{array}{l}\text { Increased evaporation and } \\
\text { evapo-transpiration leading to } \\
\text { reduced water availability, } \\
\text { reduced productivity, high costs } \\
\text { of manures and seeds, } \\
\text { droughts, heat stress }\end{array}$ & $\begin{array}{l}\text { Salinization, eutrophication of } \\
\text { wetlands, loss of production, } \\
\text { flooding of agriculture areas, } \\
\text { Destruction of crops, food } \\
\text { shortage for people and animals }\end{array}$ & $\begin{array}{c}\text { Improvement of irrigation } \\
\text { methods, flood control, control of } \\
\text { desertification and exotic species, } \\
\text { use new cultivars, make moist } \\
\text { modified grasslands }\end{array}$ \\
\hline Marine ecology & $\begin{array}{c}\text { Ocean warming } \\
\text { Sea level rise } \\
\text { erosion, coastal flooding }\end{array}$ & $\begin{array}{l}\text { Increasing salinity, chalky corals, } \\
\text { scorch reefs, loss of estuaries, } \\
\text { Change in salinity through } \\
\text { inundation, Contamination of sea } \\
\text { water from run-off death of fish } \\
\text { and other marine animals }\end{array}$ & $\begin{array}{c}\text { Flora and fauna death } \\
\text { Lagoon water temperature } \\
\text { increase, shallow turbid water, } \\
\text { inundation of low lying coastal } \\
\text { areas and rivers, saline intrusion } \\
\text { into ground water aquifers. }\end{array}$ & $\begin{array}{l}\text { Control of dumping of wastes, } \\
\text { power fishing, ocean over } \\
\text { exploitation Reduction in global } \\
\text { temperature }\end{array}$ \\
\hline \multirow[t]{2}{*}{$\begin{array}{c}\text { Coastal } \\
\text { problems }\end{array}$} & Tsunami & Devastation of islands & $\begin{array}{l}\text { Submergence of islands, coastal } \\
\text { cities }\end{array}$ & $\begin{array}{l}\text { Control underground nuclear } \\
\text { tests, development of control } \\
\text { warning systems }\end{array}$ \\
\hline & $\begin{array}{l}\text { Increased sea water } \\
\text { temperature, Rising sea } \\
\text { level, }\end{array}$ & $\begin{array}{l}\text { Reduced productivity at low } \\
\text { latitudes productivity and high } \\
\text { altitude. Increase breaching and } \\
\text { wash over events, changes in } \\
\text { community structure }\end{array}$ & $\begin{array}{l}\text { Altered ocean circulation, } \\
\text { dispersal, Gene flow, effect on } \\
\text { fresh water input, } \\
\text { osmo-regulation problems } \\
\text { due to change in salinity }\end{array}$ & Reduction in global temperature \\
\hline $\begin{array}{l}\text { Deep sea } \\
\text { oceanic } \\
\text { atmosphere }\end{array}$ & $\begin{array}{l}\text { Light penetration } \\
\text { Increased suspended } \\
\text { solids. Shift in } \\
\text { distribution of species, } \\
\text { ocean acidification }\end{array}$ & $\begin{array}{l}\text { Higher nutrients collection } \\
\text { because of mixing of urban sewage } \\
\text { and agricultural land surface } \\
\text { runoff, loss of water flow, }\end{array}$ & $\begin{array}{l}\text { Global, increased extreme } \\
\text { weather, expansion of oxygen } \\
\text { minimum zones. Body size of } \\
\text { fish reduced. }\end{array}$ & Reduction in global temperature \\
\hline \multicolumn{5}{|c|}{ Meteorological markers } \\
\hline $\begin{array}{l}\text { Weather } \\
\text { conditions }\end{array}$ & $\begin{array}{l}\text { Temperature, rainfall, } \\
\text { pressure, humidity, } \\
\text { sunshine and cloudiness } \\
\text { Precipitation } \\
\text { Wind speed, visibility }\end{array}$ & $\begin{array}{c}\text { Elevated High or low, } \\
\text { Haze and unclear sky } \\
\text { Dust clouds and storms, Low } \\
\text { visibility }\end{array}$ & $\begin{array}{l}\text { High temperature variations, dew } \\
\text { point temperature, Uneven rains, } \\
\text { floods, High heat Hurricanes, No } \\
\text { cloud or thick clouds, }\end{array}$ & $\begin{array}{l}\text { Use of satellite imaging network } \\
\text { for appropriate prediction of } \\
\text { weather conditions }\end{array}$ \\
\hline
\end{tabular}




\section{Continued}

\begin{tabular}{|c|c|c|c|c|}
\hline Total climate & $\begin{array}{c}\text { climate-warming } \\
\text { greenhouse gas emissions }\end{array}$ & $\begin{array}{c}\text { Precipitation increase, diurnal and } \\
\text { seasonal heating, increased sky } \\
\text { lightning activity }\end{array}$ & $\begin{array}{l}\text { Contamination of water } \\
\text { resources water shortage and } \\
\text { water contamination }\end{array}$ & $\begin{array}{l}\text { Control warning systems } \\
\text { on land, sea water and sky }\end{array}$ \\
\hline \multirow[t]{8}{*}{$\begin{array}{l}\text { Socio- } \\
\text { economic }\end{array}$} & River pollution & $\begin{array}{c}\text { Urban water, wastes, garbage, } \\
\text { sewer }\end{array}$ & $\begin{array}{l}\text { Noxious with heavy Fowling } \\
\text { smell }\end{array}$ & Waste management \\
\hline & Cleanliness quality & Household wastes & Fowling smell & Disposal, biodegradation \\
\hline & Food commodities & Contaminated & Disease causing & Safe storage \\
\hline & Demographic upsetting & $\begin{array}{c}\text { Wars and loss of world economy, } \\
\text { Social-racial conflicts }\end{array}$ & $\begin{array}{c}\text { Loss of human life, safety, } \\
\text { medical and clinical, economic } \\
\text { problems, migration }\end{array}$ & $\begin{array}{l}\text { Treaties for solution } \\
\text { of territorial conflicts }\end{array}$ \\
\hline & Family planning & Quantity dependent family & $\begin{array}{l}\text { Problem of food, education } \\
\text { housing and medical aids }\end{array}$ & $\begin{array}{l}\text { Strict family planning, cultural } \\
\text { and religious control over family } \\
\text { structure }\end{array}$ \\
\hline & Socialization & Breakage of social bonds & $\begin{array}{l}\text { Migration of social groups, } \\
\text { fragmentation of society }\end{array}$ & $\begin{array}{l}\text { Social education, peace, harmony, } \\
\text { social cultural exchanges }\end{array}$ \\
\hline & Community & $\begin{array}{l}\text { Medico-legal-clinical problems, } \\
\text { Hunger and poverty, illiteracy }\end{array}$ & $\begin{array}{l}\text { wages, natural resource sharing } \\
\text { and monetary value }\end{array}$ & $\begin{array}{l}\text { Education, employment, } \\
\text { self-help, child sponsorship }\end{array}$ \\
\hline & & Cultural markers & & \\
\hline \multirow[t]{4}{*}{$\begin{array}{l}\text { Cultural } \\
\text { markers }\end{array}$} & Aesthetic loss & $\begin{array}{c}\text { Destruction of river systems, holy } \\
\text { ponds and wet lands }\end{array}$ & $\begin{array}{l}\text { Tree loss due to } \\
\text { construction of urban habitats, } \\
\text { Dam construction }\end{array}$ & $\begin{array}{l}\text { Cultural development, aesthetic } \\
\text { rituals, cultural exchange, values } \\
\text { and journeys and pilgrimages }\end{array}$ \\
\hline & Loss of biodiversity & Vulnerability, life threatening & Habitat loss, extinction & $\begin{array}{l}\text { Conservation of nature, natural } \\
\text { resources, wild animals and } \\
\text { heritage sites protection } \\
\text { of biosphere }\end{array}$ \\
\hline & $\begin{array}{l}\text { Consumer-environment } \\
\text { relationship }\end{array}$ & $\begin{array}{l}\text { affects food web and the food } \\
\text { chain }\end{array}$ & Humanitarian and cultural loss & Environmental education \\
\hline & & Physiological biomarkers & & \\
\hline \multirow[t]{5}{*}{ Physiological } & $\begin{array}{l}\text { Seasonal variations and } \\
\text { gonadial stimuli }\end{array}$ & $\begin{array}{l}\text { Disturbance in } \\
\text { endocrine homeostasis }\end{array}$ & Failure of reproductive behavior & $\begin{array}{l}\text { Normal weather conditions, and } \\
\text { seasonal cycles }\end{array}$ \\
\hline & Embryonic development & $\begin{array}{l}\text { Defective cellulation, } \\
\text { blastula chocking, and } \\
\text { defaulted gastrulation }\end{array}$ & Defective organogenesis & Proper incubation temperature \\
\hline & Nesting and parental care & Effect on nest building & Embryonic death & $\begin{array}{l}\text { Normal weather conditions, and } \\
\text { seasonal cycles }\end{array}$ \\
\hline & Physiological stress & Unrest and aggression & Territorial conflicts & $\begin{array}{c}\text { Normal weather conditions, and } \\
\text { seasonal cycles, microhabitat } \\
\text { restoration }\end{array}$ \\
\hline & $\begin{array}{l}\text { Drug resistance and } \\
\text { non-clinical } \\
\text { pathogenicity }\end{array}$ & Increase & $\begin{array}{c}\text { Increased diseases states, } \\
\text { fatalities }\end{array}$ & $\begin{array}{l}\text { Change of drug formulae, } \\
\text { awareness and skill development }\end{array}$ \\
\hline
\end{tabular}

Genetic markers
Genetic biological clock

Temperature sensitivity and thermal tolerance

\section{Genetic markers}

Shift in daily activity budget

Shift in daily activity budget

High, thermal tolerance decreased Faulted physiological activity
Normal weather conditions, and seasonal cycles

Normal weather conditions, and seasonal cycles 


\section{Continued}

Salinity, alkalinity and

acidity tolerance

Drought tolerance

Diurnal activities

Thermoregulation Parentage

Territorial behavior

Osmo-regulatory

Life style diseases

Reproductive health,

Family planning and development

Clinical and nonclinical issues

Housing and leisure

Nutrients and energy supply needs

Mental and physical health

\section{Behavioral markers}

Altered timing of night shelter, Effect on reproductive behavior, Normal weather conditions, and sleep and awakening

Regression, migration, plumage changes, morphogenesis in

thermal defense decrease

Aggression

High in animals

Human health

as an overall marker

Decreased water Quality, presence of chemical pollutants to water resources

Increase in cardiovascular, gastric and neurological

$$
\text { Low }
$$

High birth rate and high death rate

Pollutants and solid dusts, aerosols

more dusts, aerosols, hazes and toxic air, poor air quality, epidemic

$$
\text { Nutrient deficiency }
$$

Poor, neurological problems, skeleton-muscular problems

No socialization, quarrels and Normal weather conditions, and group conflicts, forced migration seasonal cycles

Low resistance, death Normal weather conditions, and seasonal cycles

Intergroup and intra-group

Normal weather conditions, and Encounters seasonal cycles

High in animals

Normal weather conditions, and seasonal cycles
Respiratory diseases

Higher rate of vector borne diseases

Increase in morbidity and pre-mature untimely deaths

\section{Increase in unwanted illiterate} population

allergic diseases

Deficiency disease

Psychiatric diseases
Severe change in weather conditions

Hospitals with all facilities for care of community health and well being

Educate and train the health workers, collaborations with international health organizations,

Proper clinical care, control of vector population

Provide adequate health care facilities and services, Develop early warning systems for heat waves, floods

Provide adequate nourishment

Adequate hospital care, proper medication counseling
Normal weather conditions, and seasonal cycles

Normal weather conditions, and seasonal cycles

temperature of $21^{\circ} \mathrm{C}$ for their distribution and survival. Due to increase in temperature they have been vanished completely from colder regions with temperature below 21degree. Higher temperatures also cause the expulsion of zooxanthellae (single-celled plants living in the cells of coral polyps), which leads to coral bleaching and has caused the loss of 16 percent of the world's corals (Wilkinson, 2004). Up to a third of corals are considered to be threatened with extinction due to climate change (Carpenter et al., 2008). In a chain reaction, the death of corals causes the loss of habitat for many species of tropical fish. Other 
biological indicator of climate change is small mouth black bass fish; Micropterous dolomite which spawn only when the water temperature reaches up to 16 degree and continue spawning till $18^{\circ} \mathrm{C}$. Most effected animals are intertidal barnacles. Pectin groenlandicus never occurs before above $16^{\circ} \mathrm{C}$, where as other barnacles Balanus batanoides occurs below $22^{\circ} \mathrm{C}$. A shortage of hydrophytes affect faunal food requirements in shallow water; filth and turbidity perish aquatic fauna. Marine and coastal ecosystems are severely disrupted by cyclones as damaged corals directly through wave action submerged deep into sand sediment (Table 1).

The marine environment provides an annual stability in temperature, salinity and gaseous contents. High levels of atmospheric carbon dioxide, released after burning of fossil fuels, is absorbed by the oceans, where the gas dissolves into carbonic acid. This elevated acidity inhibits the ability of marine animals, including many plankton organisms, to create shells, disrupting life within the ocean's food web. Perhaps the most devastating effect of $\mathrm{CO}_{2}$ is destruction of habitat. Oceans absorb the extra heat but inadvertently they are facing the brunt of these changes. Ongoing efforts to safeguard ocean habitats or creation of gigantic marine sanctuaries now become highly important CSCDGC, 2002. Changing environmental conditions are favoring align species or exotic species; but later on they become invasive and out-compete native species. This species replacement is going on in exotic weeds, which become more hazardous to entire terrestrial ecosystems (Chown et al., 2010; McGeoch et al., 2010). These invasive species become highly noxious for human health as they growing faster than native species in new climatic conditions (Smith, 2000) (Figure 2).

Climate change encompasses both increase and decrease in temperature as well as shifts in precipitation, changing risks of certain types of severe weather events, and changes to other features of the climate system. Increased global temperature is responsible for loss of habitats, droughts, precipitation, and floods, melting of glaciers and indirectly for ozone depletion. Rising temperature has increased the frequency and intensity of extreme weather events like hurricanes, thunder-storms, sky lightening, hot winds, wildfires and droughts threaten the world's food supply. All these accidental changes forced the people to migrate from their homes, separate families and jeopardize livelihoods. And all of these adverse effects resulted in social conflicts, territorial wars, hunger and poverty. The impacts of climate change affect every country on every continent. Visible evidence and climbing numbers demonstrate that climate change is not a distant or imaginary threat, but rather a growing and undeniable reality. Impacts of climate change include increasing water scarcity and flood risk, along with decline in water quality.

Due to seasonal or inter-year variations in rainfall and long-term severe droughts influenced man on the environment. This leads to reduction in vegetation cover, destruction of soil and increased the wind erosion. The destruction of the natural grass and woody vegetation cover in dry lands affects the topsoil temperature and air humidity, and thus influences the movements of atmos- 
pheric masses and rainfall. Although the cycles of drought and climatic disturbances can contribute to the development of desertification, it is mainly caused by overgrazing, land clearance, over-exploitation of cultivated and natural lands, or generally using land in a way that is inappropriate to local conditions (Figure 2, Table 1).

Variations in climate not only lead to the modification of ecosystems but they also affect human social system and remain persist for longer period. A higher frequency of extreme weather events such as floods, intense tropical and extratropical cyclones, coastal storm-surges, thunderstorms are causing vast property destruction and loss of life almost every year. All these natural disasters are happening due to shifting in regional and global atmospheric temperature that is causing accidental untimely heavy rains, heat strokes and draughts. Change in water cycle and rise in earth biosphere temperature is seriously hitting trophic interactions mainly in marine waters as fish population is on heavy decline (Edwards \& Richardson, 2004; Hays et al., 2005). The IPCC has reported that increased precipitation intensity and variability are projected to increase the risks of flooding and drought in many areas (Bates et al., 2008). Therefore in future, tropical cyclones will probably occur, with larger peak wind speeds and heavier precipitation (Landsea, 2007).

More winter and spring precipitation is increasing every year in temperate climatic regions. Some portions of temperate and tropical regions have no rains and some are facing longer draughts. Longer-term droughts are expected to intensify in large areas of the Southwest, the Southern Great Plains, and the Southeast. Trends in reduced surface and groundwater supplies in many areas are expected to continue, increasing the likelihood of water shortages for many uses. Heat waves are projected to become more intense, and cold waves less intense, everywhere in northern hemisphere that is an alarm for future. Hurricane-associated storm intensity and rainfall rates are projected to increase as the climate continues to warm. The relationship between extreme weather events and climate change is not easy to establish, because they may happen at a gap of 10-20 years. A significant increase in temperature has been reported only since the 1970s. Thus, the number of events may not yet statistically support a correlation and will remain accidental (Helmer \& Hilhorst, 2006) (Table 1).

Further, globalization of markets mainly of agriculture products, seeds, fruits, flowers, vegetables, cereals and pulse merchandise mainly cross border transportation have increased the translocation of species on local, regional and continental scales. Some species have expanded their range as temperatures become warmer. Warmer temperatures have created opportunities for pathogens, vectors and hosts to expand their range, thereby enabling pathogens to be present in new geographical locations and, potentially, to infect new naïve hosts, which in some cases can result in morbidity or mortality of wildlife, livestock or humans. Diseases that were kept at low infection levels because of temperature restrictions are now reported to have become fatal and endemic. Laws banning the dumping of sewage and chemicals into the ocean and policies that foster better 
stewardship of wetlands are having positive effects. But scientists agree that drastic measures will be needed to avert the ocean crises being created by climate change (Table 1).

\subsection{Major Changes in Hydro-Biological Cycle}

Changes in earth climate are massively affecting water cycle, as it is lonely factor which assist in determination of role of other factors. As stronger changes have been observed in annual mean temperature, precipitation, sea level, river flow, soil moisture, evapo-transpiration, ground water, and cryospheric characteristics. Low precipitation and rainfalls are causing heavy shortage of fresh water on earth. It is also responsible for freshwater availability, quality and storage. Irrigation is secondary causes that results in shortage of ground water and surface water due to high evapo-transpiration. In near future it will increase alarmingly and increase with the extent and the speed of global climate change.

Climate change is imposing serious threats to fresh water diversity mainly in riverine and fresh water systems (Dudgeon et al., 2006). Globally, the negative impacts of climate change on marine water is destruction of corals and marine fishes, while in freshwater systems are loss of planktons and fish biodiversity. Streaming water and its availability in river provide the shape to ecosystem and its productivity (Woodward et al., 2010). As the riverine ecosystem possess limited dispersal abilities as the environment changes, hence it found to be more vulnerable to climate change. However, change in surface temperature of aquatic water systems and heat transfers severely affect ecosystem productivity and floral and faunal life (Caissie, 2006). Species which are living in lotic habitats are climate-dependent (Table 1). Water stream in the river is all due to precipitation, and geology, topography, soil type, and vegetation help to determine the supply of water and the pathways by which precipitation reaches the river channel (Poff et al., 1997). The hydrological and thermal regimes of rivers directly and indirectly trigger different ecological processes (Figure 2).

Human influence and intoxication of water adds pressure on biota of rivers and streams (Woodward et al., 2010). Mountain running water aquifers are also highly sensitive as temperature rise stop their uninterrupted flow due to water shortage. Aquatic organisms such as fish, most of the macro-invertebrates are ectothermic nature. Hence, they are directly and indirectly dependent on the surrounding temperatures. If seasonal overturns do not occur normally, thousands of animals die in different water thermal zones. Water temperature has been changed in sub-tropical and temperate lakes that have disrupted species distribution and animal movements. It also has indirect concern to species richness in aquatic habitat (Reyjol et al., 2007). The ecological consequences of future climate change in freshwater ecosystems will largely depend on the rate and magnitude of change related to climate forcing, i.e., changes in temperature and stream flow. These changes not only imply absolute changes (increases or decreases) but also the increasing variation between extreme physiological changes. 
Climate changes are responsible for long draughts, devastating floods, hail storms heat and wildfires. All these natural calamities are making people homeless in coastal, mountain and plane areas. Due to ongoing hydraulic and carbon stress forests are also dying-off slowly and slowly. There is ample evidence that climate characteristics are changing due to greenhouse gas emissions caused by human activities (Table 1).

\subsection{Adverse Effects on Energy Cycles and Ecosystem Productivity}

Climate change affects different ecosystems in different ways. It depends on the complexity and original characteristics of the system, geographical location and other associating factors. It also influence atmospheric energy fluxes and heat exchanges. Degraded ecosystems are generally believed to be less resilient to climate change than intact and healthy ecosystems. Changes in temperature and precipitation also affect behavior pattern in individuals, species, ecosystem richness and productivity. Weather events also effect species composition; population structure and survival because of shifting of their position in trophic levels that also affect their position in entire food-web. It lastly changes the ecological communities at the landscape level (Table 1).

Climate change is responsible for loss of plant species in fresh water, marine and terrestrial ecosystem. Extreme climate is severely affecting biotic relationships, productivity and carrying capacity of marine, terrestrial and fresh water ecosystems. It is seriously affecting biotic interactions, presence of micro-consumers mainly detrivores and disturbing carbon-cycle feedbacks. Both rising temperature and low rainfall massively affected the productivity of fresh water habitats and tropical rain forests due to loss of plant species (Shukla et al., 1990). Due to low annual rains longer draughts are seen which are responsible for sudden evoking of forest fires due to drying of biomass. Post fire seen recently happen in Australia are responsible for nudation of forests sites with heavy loss of plant and animal species, its restoration is not possible in next two centuries. This is an alarming condition for the total world, if forests disappear due to any reason stored carbon will take centuries to finish (Malhi et al., 2008; Rates of Deforestation \& Reforestation in the U.S). Forest ecosystems store approximately $45 \%$ of the carbon found in terrestrial ecosystems, but they are sensitive to climate-induced dieback. Here, landscape is an important structural factor, most of the mountain reserve forests because they use more carbon at low temperature in comparison to plane area forests. Hence, appropriate conservation strategies are to be adopted to maintain forest cover to control the global temperature rise (Deforestation and climate change, 2018). Climate variability, particularly changes in weather conditions also affect the species stabilization, its resource value and survival. In case of animals as well as in plants exotic species are replacing native ones. These are highly problematic to ecosystem dynamics because of inherent biotic potential of native species is adapted since much longer time, invasive species replace old key stone species and change trophic cascade by attracting invading insect 
pests (Walsh et al., 2016). These massively use soil nutrients, grow very fast and generate their progenies very fast, hence their number increase in no time (Walsh et al., 2016). Climate change is severely affecting land and soil resources in tropical countries (Table 1).

\subsection{Carbon Sink and Restoration of Major Blusters}

Both ocean and forests are natural reservoirs which store carbon-containing chemical compounds accumulated over an indefinite period of time. Both absorb and remove extra carbon dioxide $\left(\mathrm{CO}_{2}\right)$ from the atmosphere, and do massive carbon sequestration. Similarly, certain technologies and chemical methods can also assist in mitigation of extra carbon from atmosphere. Both absorption and capturing of carbon dioxide $\left(\mathrm{CO}_{2}\right)$ from the atmosphere are highly important steps to cut down its concentration in the air. However, to cut down level of carbon dioxide more additional forests must grown in proportion to $\mathrm{CO}_{2}$ present in the atmosphere. In this direction India has taken a leaping step and increased the green cover by afforestation in last two decades. It will create an additional carbon sink of 2.5 - 3 billion tons of carbon dioxide equivalent through growing additional forest cover by 2030 . It is a land mark step that India has made Nationally Determined Contribution at country level (INDC). The current rate of afforestation achieved is to mitigate 35 million tons carbon dioxide equivalent per year. Though it is slightly lower than what is needed to achieve the target. At this rate, there will be a shortfall from the target pledged. This target could be achieved by reducing land degradation and applying afforestation mainly development of green cover both "Open Forests" and "Shrubs" are needed (Table 1).

\subsection{Sky Lightening and Climate Change}

The potential impacts of global warming is also seen as triggering of sky lightning has been potentially increased. It results in ignition of accidental forest fires across the Mediterranean and temperate regions in the Southern hemisphere under warmer climate. According to the report published in science a $12 \%$ increase in lightning activity has been seen for every $1^{\circ} \mathrm{C}\left(1.8^{\circ} \mathrm{F}\right)$ of warming. Lightning creates around 100 strikes per second each of them of 200 bolts streak through the sky. It very swiftly hit the ground somewhere on earth around 8 million times per day. Lightning is quite hazardous; it strikes and falls very fast and kills people. It also triggers potentially devastating wildfires. Lightning flash rate depend on thickness of cloud, presence of sodium in clouds, precipitation and energy available in atmospheric air. When thick clouds hover and colloid in sky due to vertical movement of air, these generate lightning. Lightning is caused by charge separation within clouds, and maximize with charge separation. Lightning itself is also linked to variations in upper troposphere water vapor, and troposphere ozone, both of which are strong greenhouse gases. The diurnal and seasonal heating of the continental landmasses, large fluctuations in tem- 
perature and pressure changes result in atmospheric stability, it lead to development of thunderstorms. Most possibility of more intense thunderstorms, there may be an increase in the amount of lightning by $10 \%$ for every one degree global warming.

\subsection{Loss of Bio-Diversity}

Global climate changes have jeopardized the survival of both animal and plant species. Due to habitat destruction and degradation of land resources heavy losses in plant and animal biodiversity have been seen. Most of them are kept in threatened or vulnerable category and are waiting for their untimely elimination. Many of them have been declared extinct so far. Low rainfall in mountains and leaching of glaciers due to rising temperature are main factors responsible for the current loss of biodiversity in high altitude zones. In these areas tree line and snow lines have been shifted very fast upwards. Among other reasons of biodiversity loss are drying of glacier fed rivers deforestation and the draining of wetlands for irrigation and drinking water purposes (Meier, 2005; Jacobsen et al., 2012). Few species have been lost forever due to mass cutting and few are waiting for their extinction. Thus both anthropogenic activities and climatic effects are influencing both alpha and beta biodiversity. This loss is typically associated with more permanent ecological changes going on in ecosystems, landscapes, and the global biosphere. Reduced biodiversity leads to reduced ecosystem services and eventually poses an immediate danger for food security that is directly related to man.

Natural disturbances, such as wildfire, floods, and volcanic eruptions also have affected ecosystems drastically. These have eliminated local populations of some species and decreased the biotic potential and survival of biological communities. If disturbances are temporary, then these remain restorable, if persist for longer time will severely affect energy functions of ecosystems and its productivity. Though species try to modify climate induced changes up to some extent and acquire adaptations to face these challenges. Thus both direct and indirect effects of climate change result in biodiversity loss, both are concerned to productivity, but it seemingly affects food web and the food chain insofar. If one key stone species is lost, its extinction adversely affect the entire chain (co-extinction) and leading to an overall reduction in biodiversity (Figure 2). There are global indicators of biological invasion as species numbers, adverse climate and its effect on biodiversity impact policy responses (McGeoch et al., 2010).

Biodiversity on land, ocean and fresh water is under threat (Meier 2005). It is badly affected by seasonal climatic changes. However, extinction of one plant species may become a cause of loss of planktons, insects and fresh water fishes because each one of them is linked in a food chain (Ott, 2010). This is the main reason that due to rising surface temperature of water reservoirs invertebrate populations mainly insects and planktons in soil, fresh water and marine environment are decreasing very fast (Figure 2). These serve as food for other forms 
of life, also determine an area's biodiversity. In marine habitat coastal areas are worst affected as biodiversity of both vertebrate and invertebrate fauna suffered disproportionately due to manmade stresses. Habitat loss has far-reaching severely affect ocean's biodiversity including landmasses, estuaries, swamps, marshes, and wetlands. This is also noted in terrestrial ecosystems where species is not eliminated from the ecosystem or from the biosphere, but their numbers have been fall below critical level. In addition, niches have been filled by either individuals of a single species or a group of species, that has hampered biotic relationships and lower the functioning of the ecosystem. Therefore, a sudden decline in numbers may produce significant changes in the ecosystem's structure. This global biodiversity loss is irreversible and it has created major imbalances at ecosystem level that are exerting adverse effects on human and animal interactions as well as their interaction with environment (Butchart et al., 2010; Anup 2019). As biodiversity is most often associated with species richness, and it is not only loss of individuals of a population but it is loss of number of genes found in representatives of a species, individual organisms and biological communities. These ecologically adapted genes and genetic system will loss forever. There may be temporary loss but how it could be achieved is tough task. This reversible loss could be managed through ecological restoration/ecological resilience and conservation of biospheres reserves at mega scale. Long term climate changes will put major impact on human life as health determinants and health requirements both are in jeopardy (Bradley et al., 2012; Bradley, 2014).

This is also true that local biodiversity change is not occurring at major scale in comparison to global biodiversity (Gonzalez et al., 2016). Two recent data meta-analyses have found that species richness is decreasing in some locations and is increasing in others. When these trends are combined, these papers argued there has been no net change in species richness, and suggested this pattern is globally representative of biodiversity change at local scales (Cardinale et al., 2012). An area's biodiversity increases and decreases with natural cycles. Seasonal changes, such as the onset of spring, create opportunities for feeding and breeding, increasing biodiversity as the populations of many species rise. In contrast, the onset of winter temporarily decreases an area's biodiversity, as warm-adapted insects die and migrating animals leave. Sudden population declines may upset social structures in some species, which may keep surviving males and females from finding mates, which may then produce further population declines. Declines in genetic diversity will make rapid reduction in population that may increase inbreeding (mating between closely related individuals), which will cause a further decline in genetic diversity. Hence, there is a fast decline in the number of species and its individual, genetic variability, interaction among species, and the biological communities in a given area. This loss in the variety of life can lead to a breakdown in the functioning of the ecosystem where decline has happened.

Among important reasons of biodiversity loss are over-exploitation and un- 
sustainable use of land and forest resources, mass hunting of animals, armed conflicts, and human livelihood methods. Other factors are over-exploitation of economically valuable species, leading to population declines and local extinctions (Woodward et al., 2010). Land use intensification and development of urban habitats by replacing the forest cover is a negative factor for habitat loss. Other factors are heat stress and drought stress, excessive nutrient load and different forms of pollution, (e.g. unsustainable fishing methods), and invasion by alien species are replacing indigenous species (Walsh et al., 2016). Hurricanes and typhoons, storm surges, tsunamis and other sudden natural calamities cause massive, disruptions in the life cycles of ocean plants and animals. Moreover, power operated destructive fishing techniques and gears like nylon nets; bottom trawling, dynamiting, and poisoning destroy habitats near shore as well as in the deep sea. Sea water tourism and games attracts millions of boaters, snorkelers, and scuba divers, motels into direct contact with fragile wetland and reef ecosystems. Container ships and tankers also damage habitat with their hulls and anchors. Spills of crude oil and other substances kill thousands of birds, mammals, snakes, turtles and fish and leave a toxic environment that can persist for years. Due to illegal human activity and interference around $30 \%$ of mammal, amphibian, and bird species become endangered. Similarly, number of small insect species from tropical and temperate climate have been worst affected and there was observed a dramatic reduction in absolute insect biomass and number of species in colder and warm humidified zones (Hallmann et al., 2017) (Figure 2). Certain types of pesticides such as neonicotinoids and chlorinated pesticides are responsible decline of certain bird species (Pennisi, 2019).

\subsection{Effect on Mountain Ecology}

Approximately 24 percent of the earth's land surface structure is mountain ecosystems. It has steep and varied topography and distinct altitudinal zones, with high diversity of species and habitats and a high degree of endemism. Mountains also provide essential resources to human communities, both at the local level and beyond. They are particularly sensitive to changes in temperature and precipitation because of their geographical and topographic location. The highest rates of warming have been observed at high latitudes around the Antarctic Peninsula and in the Arctic, with the recorded reduction of the extent, age and thickness of ice. This is occurring at unprecedented speed and even exceeded more than recent scientific predictions (Meier, 2005). Climate changes are also affecting both alpine and subalpine forests due to increasing temperatures. Low foot hill thick forests are facing climate-induced fires causing a downward shift of the upper tree line and a consequent reduction in important cloud-forest habitat (Hemp, 2009). High mountains such as Mount Kilimanjaro beer Alpine plants are long-lived and slow growing. These have been adversely affected due to rapidly changing climatic environment as these are slow adapting. Many 
plants will respond to the changes in climate with a considerable time lag (Pauli et al., 2005). Due to rising temperatures in high altitude mountain ranges migration of animals and disintegration of vegetation patterns is going on very fast that is an alarming situation for co-adapting species in unstable transition zones (Michael et al., 1999).

Forest ecosystems are worst affected due to climate change mainly due to rising temperatures, higher evaporation rates and lower annual rainfall, with longer and more frequent droughts. This is causing higher tree mortality, increasing greater risk of forest fires. Higher temperature is also making changes in permafrost and hydrology of snow packed mountains and reducing the depth of mountain snowpack's and glaciers. It has increased the rate of seasonal snow melting, affected large downhill areas and raised the risk of flooding in lowland ecosystems (Hinzman et al., 2005). Both snow fall and snow deposition rate has been significantly slow down (Mote et al., 2005; Westerling et al., 2006). Melting of ice on mountains has increased the chances of glacial lake outbursts and steadily devastating floods in lower foot hills and plains (Bajracharya et al., 2009). Changes in stream and river flow both are affecting fresh water ecosystems and their micro and macro-fauna and flora (Figure 2). Contrary to this, increased atmospheric carbon dioxide $\left(\mathrm{CO}_{2}\right)$ level is stimulating growth and increasing the sequestration rate of forest carbon in areas with sufficient rainfall (Evan et al., 2012). Oppositely in low rainfall zones high $\mathrm{CO}_{2}$ levels imposing negative effects as decaying vegetation cover and burning of forests is a huge source of $\mathrm{CO}_{2}$. This sharp increase in greenhouse gas level has exacerbated serious climate changes and long term effects may seen in adjoining vegetation and fauna of forest ecosystem (Grime et al., 2008).

Tropical moist forests composed of evergreen trees and are formed under conditions of constant high temperature (a yearly average of $18^{\circ} \mathrm{C}$ or higher) and high rainfall (Peel et al., 2007; WWF, 2011). But tropical dry forests receive less rainfall and shelter a very different suite of species. These include many deciduous species that can shed leaves during dry periods. These are highly prone to forest fires. Where there are no prolonged dry spells (Whitmore, 1990) and a sharp reduction in rainfall is noted such tropical moist forests will convert into tropical dry forest. Reduced rainfall and humidity loss make the biomass dried that is more prone to fire regimes (i.e. the pattern, frequency and intensity of fires). Today this is most apparent effect that is seen in drier forests of Australia where forest fires gutted thousand hectares of living forests and wild fauna. Last year sudden evoking of fire in Amazonian forests gutted a population of plant and animal species (Cochrane \& Laurance, 2002). Though it is a recurrent event in tropical forests but it is severely affecting forest structure, biomass, and species composition (Cochrane \& Schulze, 1999). Forest fires have diminished the survival of seeds in the soil, thereby regulating grass productivity (Gandiwa \& Kativu, 2009). This shortage of food mainly preferred to insects, results in increased negative interactions among them, both parasitism and predation get 
increased. At next trophic level all dependents in food chain could not found eatables hence members of their species will not survive more in number (Eliasch, 2008). It will also affect next trophic level. Thus all such change will severely affect species richness, survival and adaptability of both flora and fauna.

Climate change is also affecting the productivity of vegetation and the composition of grassland species (Weddell, 1996). Yearly droughts or low rains are making a shift to less productive, more drought-tolerant plant species from naturally adapted normal forest vegetation (Grime et al., 2008). This change, in turn, is affecting the presence and behavior of species that feed on such vegetation. It will cause a more silent population collapses within wildlife species, as it was recorded in Gonarezhou National Park, Zimbabwe, where 1500 African elephants died after severe drought in 1991-1992 (Gandiwa \& Zisadza, 2010). Major impact is extinction or threatening of wildlife, or their disappearance in habitat or shifting to geographically distant places. Primates are also facing major challenge from highly negative effects. As International Union for Conservation of Nature and Natural Resources (IUCN)'s Red book Listed 48 per cent of primate taxa as threatened species (IUCN/SSC, 2008). Endemic species with strict ecological constraints are likely to be most affected.

Climate change is severely affecting grassland ecosystems, as elevation in temperature and less rain in summer season has increased the rates of evaporation, and decreased the soil moisture. Changes in temperature and/or precipitation caused considerable shifts the distribution of grassland bird species; these species are expected to decline as a consequence of climate change. Changing climate will decrease flowering plant species that will decrease bird population (North American Bird Conservation Initiative and US Committee, 2010). Long term draughts and other prevailing conditions are doing massive killing of soil fauna and micro flora. Drought also kills many tree and succulent species as well as affecting variation in the life cycles of remaining species. This is also responsible for decline in bird populations and other wildlife that rely on such plants (Gandiwa \& Zisadza, 2010).

\subsection{Melting of Mountain Glaciers}

Due to global warming mountain glaciers are disappearing and constantly decreasing due to melting. It is adding to rising sea levels, which in turn increases coastal erosion and storm surge like hurricanes and typhoons. Two big mountain ranges Alps to the Himalayas are becoming nude due to dramatic melting of glaciers and shifting of land masses towards high mountains (Haeberli \& Ambio, 1998). Although only a small fraction of the planet's permanent ice is stored outside of Greenland and Antarctica, these glaciers are extremely important because they respond rapidly to climate change and their loss directly affects human populations and ecosystems (Fell et al., 2017). Continued, widespread melting of glaciers during the coming century will lead to floods, water shortages for millions of people, and sea level rise threatening and destroying coastal communi- 
ties and habitats.

Natural causes of glacier melting are solar variability and volcanic eruptions. Approximately 200,000 glaciers were in mid 19th century at present about two thirds glaciers are severely affected and melting very fast due to human influences on the climate. Even if precipitation increases, mass balance may decline if warmer temperatures cause precipitation to fall as rain rather than snow. Mass change is reported in cubic meters of water lost, or as thickness averaged over the entire area of the glacier. Because mass changes are difficult to measure, glacier shrinkage is more often described as a loss of glacier area, or as the distance the front (terminus) of the glacier has retreated. In comparison to anthropogenic warming caused carbon dioxide emissions, variations in solar radiation and the effects of volcanic eruptions, which can lower temperatures by blocking solar radiation, now play only a minor role in influencing whether a glacier recedes or expands. The study found that about 25 per cent of the global loss of glacier ice that occurred between 1851 and 2010 could be attributable to human influences, but that this rose to about 69 per cent between 1991 and 2010, based on computer simulations of the climate that included natural and man-made effects.

\subsection{Destruction of Ecosystems}

Global warming has decreased the rate of snowfall in high mountain ranges; that resulted in decreased water availability in rivers and rivulets. More specifically, thermal changes in polar regions caused a slow rate of ice formation and breakup rate is high that is an alarming situation for sea shore countries. It has speed up the water current and over flooded glacier-fed river systems (Jacobsen et al., 2012; Smith, 2000) and causing large-scale devastation of human lives (Kaushal et al., 2010). Flood water washed away food crops and leading to food shortages and starvation. On the other hand lack of water in summer affect dynamics and ecology of rivers and reduction in catchment area and productivity. Water shortage also affects quality and oxygen availability for fauna and their body metabolism. Its severe consequences are damage to natural wealth and long-term economic losses. It has cut down the production of food grains and pulses and fishery. Either there are heavy droughts or heavy rains, both are unpredictable. Lotic river water fulfill various development needs, it is used mainly for agriculture and hydroelectric power generation. Further, a sharp elevation of temperature in spring season made further enhancement of river water temperature that severely affected fresh water biodiversity Caissie, 2006; Poff et al., 1997; Wilby \& Harris, 2006) (Figure 1).

Urbanization significantly contributes to the increase in water pollution, especially in the form of sedimentation, solid waste, rubbish, effluents from livestock farms, and inorganic and organic pollutants in industrial discharges. Inefficient waste disposal systems and lack of proper sanitation facilities lead to waste and sewage ending up in rivers. Large scale house hold wastes, pesticides, herbicides, garbage are mixing in river water. It is affecting BOD level of river water and 


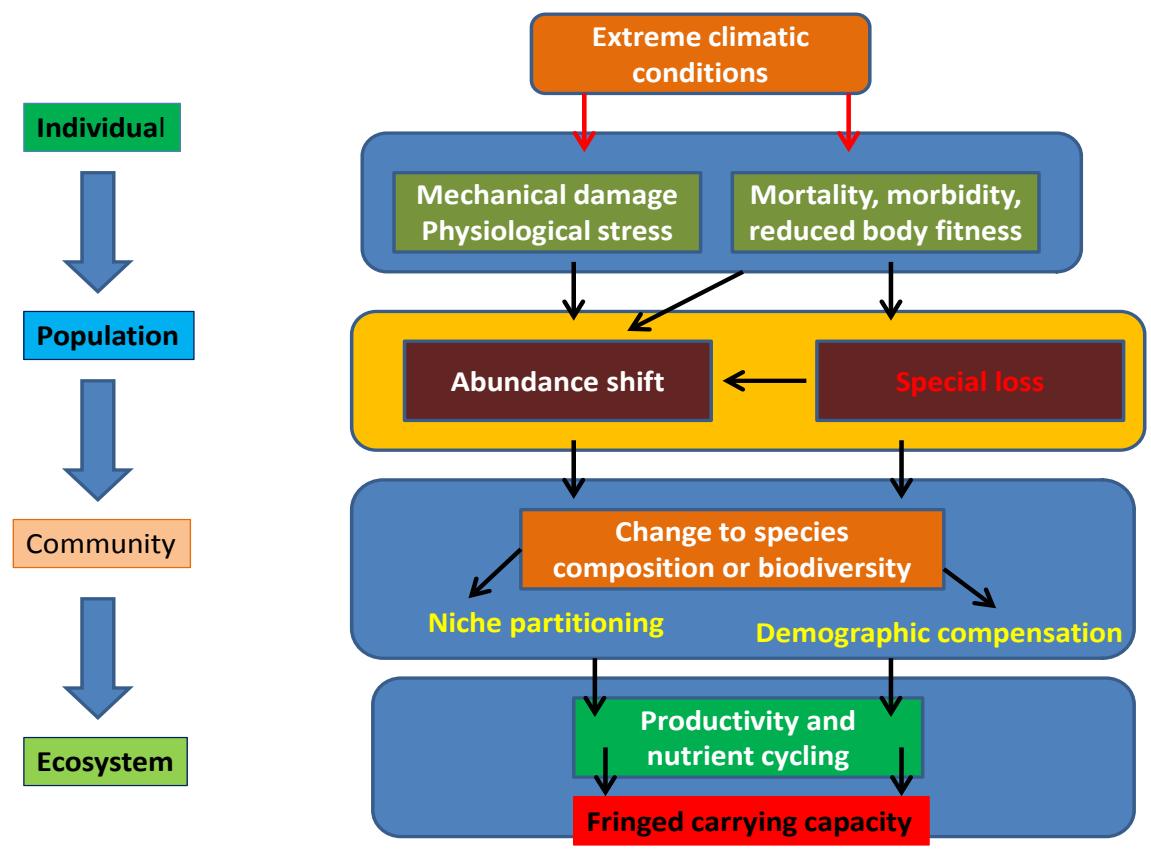

Figure 1. Sequential effect of extreme climate changes on ecosystem and its populations.

posing great threats to water fauna and flora. The reduction in river water quality is a clear indicator of the decline in the environmental health of a river basin. Other sources of urban pollution are sewage water, hospital waste, housing and road construction and automobile discharge. Sewage fed rivers become breeding grounds of insect vectors and provide surface for harmful bacteria and viruses. Due to low BOD level, high SPM, acidic $\mathrm{pH}$, presence of metal toxicants resulting in loss of reproductive ability in fish and other aquatic organisms.

Urban wastes and effluents mixing is a common problem in most of northern Indian rivers. It has resulted in loss of plankton population finally reduced primary productivity in rivers, rivulets, lakes, ponds and wetlands. Some Northern Indian rivers like Ganga, Yamuna, Gomti, Gandak, Chambal, Damodar and Koshi getting regular pollution feeding thickly populated urban areas. This is a major challenge to the survival of rivers and sustenance of flora and fauna of these rivers. Construction of large dams normally created after channelization of rivers results in loss of riparian vegetation, heavy loss of fish and plankton species. Dam construction severely affects natural flow, water quality, limnological chemistry and biodiversity. Soil, sand and sediment deposition is resulting in alteration of the natural river ecology and hydrology. However, cleaning of big rivers such as Ganga adjoing rivulets and wetlands will become helpful in restoration of hydrological cycle. Vitality of rivulets will also assist in restoration of river environment. Waste water which is flowing in nallahs or sewers, released by households and municipalities; before dropping into river water, should be recycled and purified.

Wetlands provide an abundance of essential ecosystem services, including water storage, storm protection, and flood mitigation, water purification through 
retention of nutrients. Wetlands recharge groundwater and are essential habitat for many plants and animals. Large scale destruction of wet lands is going on due to dumping of dredged and nutrient-rich organic urban waste (Sievers et al., 2018; Chen et al., 2018). In addition, toxic chemical effluents from industries and agriculture field are also creating problems fauna and flora of wetlands (Rahman, 2016) (Figure 1). Destruction of wetlands is also detrimental to our economy, recreation like fishing, hunting, and wildlife watching generate more than $\$ 22$ billion annually. Wetlands destruction has increased floods, droughts, nutrient runoff, water pollution and shoreline erosion, and a significant decline in wildlife populations. Destruction of wetlands is a systemic problem which is becoming due to human-induced environmental changes. It is resulting large number of deaths of water fauna and flora due to drying (Sievers et al., 2018) (Figure 1). These will need cooperative planning among communities, nonprofit organizations, governments, and industry. An effective strategy for protecting coastal wetlands includes a coastal marine spatial planning effort focused on the shared goal of identifying future competitive uses and impacts. Due to pollution and rise in surface water in lakes/wetlands aquatic animals' loss their life (Agriculture \& Climate Change-Draft 21). Essential stakeholders includes coastal community governments, shippers, port authorities, recreational and commercial fishing interests, the Coast Guard, pipeline companies, utilities, and state and local resource agencies.

The massive effect of climate change can be seen in semi arid zones where desertification is going on very fast. It is a global phenomenon that is reducing the natural potential of the ecosystems and renders rural populations vulnerable to food shortages, the vagaries of weather and natural disasters. Every year thousands of acres of land mainly productive/fertile farm land and grasslands are transforming into dry lands due to lose of moisture, ruining of plant communities, and wildlife (Figure 1). Fertile land is transforming into hyper-arid or desert due a major shift in day night temperature. Among main causes of desertification are severity of the climatic conditions such as large reduction in annual rainfall; humidity, shifting in day and night temperature and population pressure. The relations between desertification and drought on the one hand, and human influence on the other, are unknown and complex. Desertification leads to degradation of the land in arid, semi-arid and dry sub-humid areas resulting from various factors, including climatic variations and human activities (Figure 1).

In last six decades climate change engulfed thousands acres of productive lands, caused land degradation, and increased the greenhouse gas fluxes in terrestrial ecosystems (Working Group III Technical Support Unitc/o Imperial College). Global warming caused a regular increase in desert expansion at global level it is due to larger difference in day night temperature, humidity and rainfall (Zeng \& Yoon, 2009). Desertification also reduces agricultural yields and accompanied by a reduction in the natural potential of the land and a decrease in surface and ground water resources. There must be sustainable development of dry lands for combating desertification. This physical expansion of deserts could 
be managed by opting long term plans and converting dry lands in to moist modified grassland ecosystems by rain water harvesting, check dam construction and canal system (IPCC Special Report on Climate Change 2019; Rafferty \& Pimm, 2019). Presence of irrigation water will restore the soil structure and could increase the biological productivity in dry lands with afforestation of shade saplings (Breman, 1992). Long term master plan should be applied to land use, restoration of dry lands or development of dry land farm lands into productive forest and grassland canopies (Helmut \& Lambin, 2004) (Figure 1). For implementation of these programs more comprehensive and participatory approach is needed. Proper schemes should be launched for with flexible technical and financial assistance.

\section{Socio-Economic Markers}

\subsection{Hunger and Poverty}

There are three dimensions of poverty determination availability of wages, natural resource sharing and monetary value. In last three decades, a fourth dimension of steep population growth has been emerged that is hindering economy and consumption quality and fulfillment of daily needs. At international level poverty is determined based on the monetary value of a person's consumption but in reality it directly related to food availability. Production of food grains has been cut down to half in some regions. Approximately $8 \%$ of world population is living in extreme poverty. After all efforts made by world bank, IMF and united nations welfare schemes still almost every tenth person is living in extreme poverty, though this rate has been decrease but not up to desirable level. The vast majority of the world's hungry people live in developing countries, where 12.9 percent of the population is undernourished (Webb et al., 2018) (Figure 2). The condition of sub-Saharan countries is quite miserable.

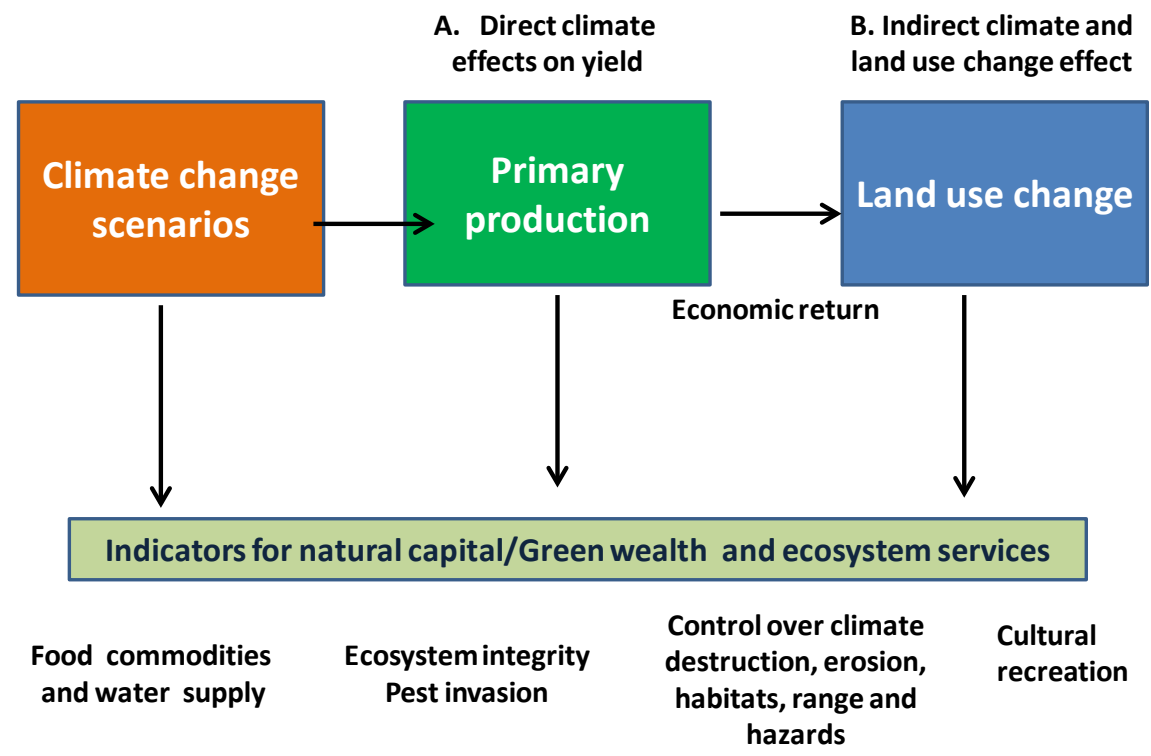

Figure 2. Effect of climate changes on ecosystem functions, bio-diversity and production. 
Worst affected demographic section is child, mother and old age people. There is a major problem of nutrition, water and housing and various world forums and organizations and federal governments are assisting to improve condition of women and children (Global Nutrition Report, 2014). The same has been expected from public and private sectors to come up and lead the charity work for arrangement of healthier diets, fruits and vegetables, clean water, and working with governments to improve health and nutrition services. In this behavior organization NGOs and private institutions can assist in building social attitudes, behaviors, and structures that support gender equality for people and communities. Child sponsorship is one of the best ways to give children better lives and futures (Figure 2). Sponsoring a child through World Vision India is one of the most effective, inspiring and rewarding ways to help children. Efforts are going on by World Bank to finish poverty by 2030 .

\subsection{Wars and Loss of World Economy}

Climate change has adversely affected the human thoughts, social system, culture and economic policies. Due to territorial conflicts war torn countries are facing heavy devastation of public property, human life and agriculture. Both terrorism and wars have cut down the rate of industrial growth and alternatively targeted the GDP. Post war conditions are worst as there remains a heavy demand of drugs, food, shelter homes, restoration of structures, and check on migration. Now concept of war has been changed, it is not a direct encounter of armies, but become a trade war. It weakens the economy of enemy country and destroys the GDP by economic sanctions. War also covers the economic mobilization of labor, industry, and agriculture leading to economic failure (Rasler \& Thompson, 1985). Both heavy taxes and prohibition of trade put states in to economic warfare such as the blockade of issues closely related to the economy, such as military issues and technology development as nuclear one. However, economic crunches could be managed by mobility of educationists, technologists and economists towards the developed countries. This migration of efficient and skilled people made developed countries stronger rather than developing countries. A report on the global human impact of climate change published by the Global Humanitarian Forum in 2009, estimated more than 300,000 deaths and about $\$ 125$ billion in economic losses each year, and indicating that most climate change induced mortality is due to worsening floods and droughts in developing countries.

\subsection{Climate Change and Human Migration}

Climate changes have severally affected the productivity of cropland ecosystem and maximum numbers of wages to daily workers come from agriculture farming (Figure 2). Loss of productivity results in loss of livelihood means, live stock, gardening and fishery. People have migrated to cities for wages from hill states in India; it has disrupted socialization among people. Not only in India but also 
at global level social conflicts have been increased due to weakening of ecological productivity, land use pattern, and water resource base. Because of artificial physical structural dependence, it made the system less sensitive to the environment. Because of rising sensitivity and minimum adaptive capacity anthropogenic climate changes, have increased the vulnerability and give rise territorial conflicts. Over industrialization has changed the scenario as the climate based weather cycle has been changed the life of the people and all around pollution and global effects of rising temperature has imposed climate-related migration (Figure 1).

There are both spatial and temporal patterns of climate-related migration. Displaced people need, societal well-being in new environment, but it is only possible if state policy consider them under inclusive development. It generates more vulnerable groups which remain unsatisfied and live under extreme scarcity of resources. Hence, extremes of climate change possibilities kept in mind before making any policy. Besides, ecological factors human interaction in groups, their living in different social systems, communities and households within particular systems also shape few differences. These differences are shaped by a variety of factors i.e. nature of climate; degree of exposure; sensitivity of human systems to such changes; and the capacity of the exposed population and its socioeconomic adaptability (Adger, 2006; Smit \& Wandel, 2006). Though, certain types of socioeconomic systems are inherently more sensitive to climate-related environmental changes, therefore they are more likely to engender adaptive migration. These social systems are characterized by agricultural and natural resource-dependence. Most of these people live in risky zones due to availability of easy livelihood means. People living in low-lying coastal areas, small island states, and other flood water zones get larger exposure to climate-related risks, and their livelihood possibilities are very limited (Meze-Hausken 2000; McLeman, 2006; PerchNielsen et al., 2008; Tacoli, 2009; Hunter, 2005).

Almost similar condition is also with the people of mountain region where majority population depends on agriculture. These high mountain areas remain frequently disrupted due to damage from regular floods, landslides in rains and droughts in hot summer. In cold they receive extreme snowfall. Demographic structure shows a large section of poor who are more vulnerable to extreme climate events. In hill states of India where near about $27 \%$ population lives below the poverty line. Frequent droughts lower down the production of agricultural commodities, which in turn push their prices up. However, after seeing extreme devastation due to climate change; people are forcibly migrating to urban areas in search of wages and employment. Though migration of people was also occurred in long historic past but those were not so destructive because need of people were minimum, post industrialization has increased the population pressure because of development.

Post migration establishment also depends on climate based stimulus-response, interaction of environmental changes or events with human social, economic, and cultural processes (McLeman \& Smit, 2006; Hunter, 2005). Though so many 
vulnerability to climate change have been identified as being a function of exposure to the impacts sensitivity of communities or socioeconomic systems but capacity to adapt in new conditions will remain an area of future research (Stacey \& Fellows, 2002; Meze-Hausken, 2000). Changing weather conditions, on two sides of world are alarming, on one side there is ice shelling in Northern American countries, people are facing super cool temperature while Australia there are no rains, people are facing longer droughts and rising temperature. Recently, climate related population displacements have been seen in the Caribbean basin where people are facing negative climatic exposure. Migration responses to climate change may therefore be treated as one of the range of possible ways by which people may adapt to adverse impacts of climate change or take advantage of resultant opportunities. Therefore, for minimizing the fatalities more ecological research methods be needed to physical and human impacts of climate change by developing alarming systems (Glantz, 1991; Gutmann \& Field, 2010, Rosenzweig \& Hillel, 1993).

\section{Biological Markers of Climate Change}

\subsection{Effect of Seasonal Climatic Variations on Endocrine Homeostasis}

Seasonal variations which occur year after year affect thyroid function in animals. Thyroid hormone diffuses into target cell through the plasma membrane. From where it reaches into the nucleus and interacts with mRNA by forming a complex in presence of calcium ions and receptor protein. Here it stimulates transcription of some inactive genes found on mRNA or inhibit transcription of some active genes (Mormede \& Terenina, 2012). Because thyroid and ecdysone hormones regulate metamorphosis in insects, their level rises during breeding season. But due to stress imposed by rising temperature cell cannot fully utilize thyroid and other hormones and its circulating amount increases. Severe adverse effects of temperature are also seen in form of disruption of cellular functions of other hormones secreted from pituitary, parathyroid, adrenal, thymus, pineal gland, pancreas and gonads. Stressor effect generated due to smelting heat, reaches to the brain cells mainly sensory neurons, and generates more motor impulses without any directive function or objective. Consequently, more epinephrine is secreted, in all organs of sympathetic fibers and large amounts of both epinephrine and nor-epinephrine is poured into blood by adrenal medulla. This extra release of adrenal hormone generates violent stress reactions, which also directly affect reproductive behavior in animals. It imposes state of shock and elevates $\mathrm{O}_{2}$ consumption and BMR both with high tension and rise in blood pressure. Hormones secreted from pituitary gland, TSH, prolactin, growth hormone and gonadotropins, FSH, ICSH, LH, testosterone are also affected by meteorological alterations which occur throughout year (Celec et al., 2009). Disturbance in FSH and LH secreted by gonadotriphic cells stimulates growth and activities of gonads. Their secretion is initiated by a genetic biological clock located 
in the hypothalamus. In such as state more active bio-molecules prostaglandins are also secreted almost by every tissue. These effect influxes of $\mathrm{Ca}+$ ions into target cells or formation of intracellular messengers i.e. cAMP and cGMP in them. Main negative modulators decrease the excitability of neighboring neurons are the amino acids mainly glycine and gamma amino butyric acid.

During the phase of sexual quiescence somniferous tubules undergo changes in which large amounts of lipid material is accumulated in them. Both Sertoli or cells of Leydig and interstitial cells are temperature sensitive cells. Seasonal variations in physical factors stimulate gonads that induce secretion of male hormones, testosterone and androgen (Zaime et al., 1992). Both are steroid hormones which also regulate secondary sexual characters at puberty. Androgen level is elevated with the temperature and food suitability and deceases in adversities of temperature. It's level is seriously affected in hibernating mammals (Saboureau et al., 1980). In animals the production and release of spermatozoa are precisely controlled either environmentally and hormone physiologically. Proliferation of follicular cells and establishment of egg organization is also affected by internal environmental changes. Elevation of temperature severely affects formation of cortical granules, pigments, enzymes and hormones, proteins that play in differentiation and maturation of eggs. Temperature and rising heat are responsible for meiotic arrest during oogenesis. It also effect sperm survival in males and cause azospermia. In adults sex hormones determine shape and function of female brain during hormonal transition period if temperature varies; it results in abnormal consequences (Barth et al., 2015). Thus environmental exposure plays significant role in developmental physiology of animals mainly in cellular differentiation and proliferation (van den Bosch \& Meyer-Lindenberg, 2019).

\subsection{Effects on Cellular Metabolism}

Heat generated stress affect the level of hormone and its action towards targeting cell. It also affects cellular metabolism by changing membrane permeability. It generates disturbance in physiology of certain neuro-hormones and neurotransmitters. It hampers activity of trans-membrane proteins which work as ion channels and operate facilitated diffusion of $\mathrm{NA}+\mathrm{Ka}+$ and $\mathrm{Ca}+$. Both heat stress and high temperature significantly alter conformational structure of ion specific pump proteins (Popoli et al., 2011). Heat waves cause rapid dehydration of body that affects action mechanism of protein hormones and catecholamine secreted by adrenal medulla. Receptor proteins of these hormones are also large transmembrane integral proteins of the plasma membranes. It catalyzes hydrolysis of several ATP molecules in cytosol. It needs presence of magnesium or manganese ions to change ATP molecules into cyclic adenosine monophophate (cAMP). It stimulates protein kinase by phosphorylation. Finally an enzyme phospho-diestrase degrades the additional molecules of cAMP to bring their number to normal. Excessive cold, heat and high temperature affect function of cGMP, diacyl- 
gycerol inositol triphosphate, eicosanoids, growth factors and certain neurotransmitters.

During physiological stress, adrenal glands secrete hormones that affect entire body physiology. Hormone cortisol prepares us to adapt physically and mentally to the stimulus. Following a major or repeated stress individual may has no control; however, cortisol is secreted in great quantities over a long period of time. This hyper secretion shows damaging effects on the individual, and accelerating aging. It facilitates the onset of illnesses such as depression. But all such events are regulated up to some extent but sudden elevation in stress remains intolerable. Hence, the only way is to either fight against such stress or migrate or die off in super trauma. Though, corticosterone tries to modify the intensity of neurotransmitters made by excitatory synapses. This stress hormone mobilizes the receptors and increases synaptic plasticity. In addition stress induced peptides play important role in neurophysiology and hormonal regulation and body metabolism (Fieber, 2019). Hormone deficiency decreases thermal tolerance and metabolism but not water loss in an invasive reed frog (Davies et al., 2015). Effects of elevated $\mathrm{CO}_{2}$ and temperature also affect plant growth (Veteli et al., 2002), flowering, seedling formation and vegetation structure mainly alpine landscape (Riedo et al., 2001). A decrease in $\mathrm{O}_{2}$ concentration and elevation in $\mathrm{CO}_{2}$ and temperature variations significantly affect cellular respiration in cell protoplasts (Lammertyn et al., 2001). A slight alteration in temperature causes lowering of metabolic rates in animals (Ducommun et al., 2002). At optimum physiological temperature production rate of the protein of interest get increased by 6 fold compared to the value at 37 degrees $\mathrm{C}$. Increased atmospheric concentrations of carbon dioxide $\left(\mathrm{CO}_{2}\right)$ resulted in increased ocean acidification. This can affect some marine animals' general cognitive performance and sensory abilities they use to forage. It could even affect the way their brain's cells talk to each other through neurotransmitters.

\subsection{Drug Resistance and Non-Clinical Pathogenicity}

Climate induced mutations confer resistance to adversities, stresses and traumas. Though changes happen very slowly against extreme events, but these are rare and remain undetected. The genetic switches found in bacteria are more susceptible to temperature sensitive binding proteins, which alter the behavior of genes accordingly to generate thermal tolerance up to some extent. Similarly, resistance against target drug is evolved step wise, and altered gene function foiled the action of drug in two steps. In an environment by the addition of drug, the drug resistant mutants favored and replaced the normal bacteria. There occurs directive selection in bacteria that non pathogenic strains are converting into pathogenic and later on into resistant one. It might be thought that the mutations conferring resistance are actually caused or induced due to exposure to drug, but it is not true. It is natural phenomenon that drug resistant mutations occur in bacterial cells irrespective of the presence or absence of the drug 
(Holzknecht et al., 2010). This is the nature of bacterial cell that mutation occurs simultaneously without exposure to drug. This is an open race among man and microbes to sabotage each other to acquire fitness through natural selection. Both shield and attack are becoming more advanced and are proving lethal tools for each other. Though, in the past and even today microbes have attained required resistance against thousands of synthetic drugs through making changes in genetic system (Chang et al., 2015). A far reaching truth is microbes are un-conquered warriors on this earth because of their sharp and finest selection than any other micro-organism. It has also ascertained their survival in extreme climatic conditions both outside host or in exenic conditions. Newly emerging virus strains are more lethal to man and his environment because of negative effect of pollutants, drugs and temperature variations. Genetic reshuffling and altered gene function is responsible for formation of new variants of genotypes of different viruses. This will remain as an unending process because environmental exposure remains unidirectional.

\subsection{Disturbances in Circadian Rhythms, Breeding and Parental Care}

Day periodicity or photoperiodicity is highly important for controlling gonadial activity or regression, migration, plumage changes and morphogenesis in animals. It is disturbed by clouds, dusts, haze, and windy storms. Light energy shows direct effect on morphology, physiology, growth development, reproductive behaviors and survival of most of the plants. Ozone layer depletion is harmful as it presents the short wave radiation from the sun, the surface of light effect metabolism, photo-pigments, vision, visual pigments, skin color, protective coloration, color changes effect on locomotion, photo taxis.

\subsection{Effect on Embryonic Development/Inductors}

Increasing environmental temperature is affecting developmental rate in animals. Normally development occurs faster at higher temperatures but only within tolerable thermal limits. Normal temperature during embryonic development shows persistent effects on thermal acclimation capacity in zebrafish (Graham \& Johnston, 2012). Embryonic inductors play vital role in embryonic development mainly in neural competence, it is affected by environment as ectoderm cells from neural tissues proliferate to form organ system. The environmental factors either biological (e.g. Viruses) or non biological such as physical factors e.g. temperature, irradiation, mechanical disturbance and chemical factors such as drugs, environmental chemicals, microbial pathogen and dietary imbalances or malnutrition target body metabolism. Heat shock stimulus induces puffing in a restricted segment of the Drosophila polytene chromosomes mainly amplification of gene activity of selected genes which regulate synthesis of specific products. Climate change is causing reversible changes such as histone acetylation and deacetylation in insect genomes. This increasing temperature is proved to be a teragtogenic factor because of its high intensity and exposure period. Both heat 
and cold induce parthenogenesis. Activity of teratogens also depends on environmental factors mainly temperature, above physiological limits or extremes of temperature; action of teratogen accelerates and makes genetic changes in cells. Thus when Drosophila larvae are exposed to elevate temperature above $40^{\circ} \mathrm{C}$ certain specific puffs appears known as heat shock puffs. Nuclei get 100 fold enriched for heat shock gene specific mRNA. In amphibians, ecologically metamorphosis is associated with a transition from an aquatic to a terrestrial mode of life. Superimposed on this change of environment a change in feeding habit occurs in anuran amphibian's frogs and toads. Tadpoles of most frogs and toads feed on vegetable matter. Particles of plants living and decaying which they scrap from submerged objects.

Global warming is intensifying interest in the mechanisms enabling ectothermic animals to adjust physiological performance and cope with temperature change. A sudden dramatic change in temperature caused more persistent effects on thermal acclimation capacity of these animals. It also put adverse effects on embryonic and post embryonic development and multiple levels of their biological organization as it is seen in bream (Abramis brama L.) (Kucharczyk et al, 1997). Though, thermal acclimation capacity in these animals is not fixed and modify according to temperature exposure received during early embryonic development. Developmental plasticity thus ectothermic organisms to adapt and resist the temperature variations but future changes will depend of climatechange scenarios. Elevation in ambient temperature also affects total body water permeability functions i.e. ECF and homeostasis.

\section{Thermoregulatory Markers}

Temperature maintenance is important to determine early thermoregulatory ability in birds. Temperature fluctuation in breeding season effect nest microclimate and disturb post hatching development and parental care in birds (Mueller et al., 2019). Therefore, physiological temperature is essentially required for egg incubation during embryonic development and post hatching periods in birds (Matysioková \& Remeš, 2018). If mother birds do not find suitable incubation condition they are forced to either shift baby birds to safe locations but it increases the risk of predation (DuRant et al., 2013). Thermoregulatory responses affect neurophysiology in young growing brains because temperature influences the formation of new neurons in adult animal brains (Youssef et al., 2014). Increased temperature severely affects gene expression in nerve cells, their structure, and even organization of brain. In addition, ambient temperature is important for habitat maintenance, incubation behavior and feeding in newly emerged baby birds (Amininasab et al., 2016). Temperature regulation is also essential for over all maintenance of reproductive behavior in birds (Esposito et al., 2017; Öberg et al., 2015). Temperature also affects cognition behavior in animals and imposes inducing trauma-responsive cognitive states. Both high and low temperature affects neurophysiology, sleeping, and learning and reduces the capacity to properly recognize stimulus and alter behavior in response to 
threats posed by climate change.

Whether conditions mainly temperature scramble migration in birds. Climate change leads to differential shifts in the timing of annual cycle stages in migratory birds (Tomotani et al. 2018). Temperature also affects migration in Monarch butterflies (Danaus plexxipus) that migrate from Eastern North America, overwintering in Mexico, and making return migrations in the spring. These butterflies employ a time-compensated sun compass to navigate right direction. Altered temperature affect their sense of direction and moths fly in wrong direction during spring migrations. It also affects finding the migratory route and impairs osmoregulatory capacities in Atlantic salmon (Salmo salar L.) (Bernard et al., 2019) to cope against stress responses in fresh and seawater (Jeffries et al., 2018). Elevated temperature seriously affects endocrine functions (Bernard et al., 2018) circadian rhythms and breeding in fish (Cowan et al., 2017). A combined stress due to salinity and temperature seriously affect osmoregulation in European sea bass Dicentrarchus labrax (Masroor et al., 2018). Temperature variations affect thermal tolerance (Shaughnessy \& McCormick, 2018), rate of oxygen consumption, feeding, liver and muscle metabolism (Sur et al., 2019) and growth in marine and aquatic animals (Magnoni et al., 2018).

More specifically, upper thermal tolerance affects growth in brook trout and their relationship to stress physiology (Chadwick \& McCormick, 2017). Fish Perca fluviatilis beat up salinity and temperature related stress by increasing plasma osmolality and oxygen consumption (Christensen et al., 2017). More often, discordant shifts in temperature and precipitation affect montane biodiversity (McCain \& Colwell, 2011). Thus heat generated by metabolism plays important role in keeping the body warm in endothermic animals. Temperature affects both aerobic and anaerobic metabolism in plants and animals. The within-species relationship between resting metabolic rate and temperature reflects the acute thermodynamics in organisms. As temperature increases, more ATP is required to fuel processes driven faster by higher cellular kinetic energy; at least until acclimation processes take effect (Schulte, 2015). But temperature imposes more negative effects in ectotherms to a changing environment conditions during aerobic metabolism. Hence, animals display more energy expenditure in aquatic habitat as temperature shifts make them more uncomfortable.

\section{Genetic Markers}

\section{Temperature-Sensitive Gene Mutations}

An elevation in temperature synthesizes heat shock proteins which differentially regulate promoter activity. This is also responsible for generation of temperature-sensitive mutant variants. All these variants work normally at low temperatures, but show altered function at higher temperatures or at the non-permissive temperature. Most temperature-sensitive mutations affect protein structure and function. At permissive temperature protein typically can fold properly, but at higher temperatures, the protein structure become unstable and ceases to func- 
tion properly. These mutations are usually recessive in diploid organisms. When a temperature-sensitive mutant is grown in a permissive condition, the mutated gene product behaves normally (meaning that the phenotype is not observed), even if there is a mutant allele present. This results in the survival of the cell or organism, as if it were a wild type strain. In contrast, the non-permissive temperature or restrictive temperature is the temperature at which the mutant phenotype is observed.

Normally in nature environment induced conventional gene knockouts or heat-sensitive or temperature-sensitive mutations take place. These temperature sensitive mutations are valuable tools for studying the behavior of normal genes in adverse environmental conditions. These may also play important role in conditional inactivation or activation of specific genes. Moreover, transcriptional output of these genes may be temperature effective and detrimental for both embryonic and adult life in temperate environments. Ts mutations are typically mis-sense mutations, which retain the function of a specific essential gene at standard (permissive) low temperature. But high non-permissive temperature, exhibit partial (hypomorphic) changes and function at an intermediate (semipermissive) temperature. Such mutants make possible the analysis of physiologic changes that follow controlled inactivation of a gene or gene product by shifting cells to a non-permissive temperature. The frequency of sites mutable to a reduced or conditional function is highly gene-specific; for example, for highly conserved proteins, random single mis-sense mutation would be expected, for the vast majority of positions within the protein, to cause complete loss of function when mutated. These Ts mutants have been identified in bacteriophage T4 genome (382 mutations located in 37 genes) (Edgar \& Lielausis, 1964; Hartwell et al., 1973). Lee Hartwell reported the isolation of 400 Ts mutations in S. cerevisiae cause defects in essential processes including cell division, and protein, RNA, and DNA synthesis (Hartwell et al., 1973). Ts alleles in essential genes found in "haploid convertible" heterozygous diploids $S$. cerevisiae, (Ben-Aroya et al., 2008). Essential genes encode critical cellular functions that are not buffered by redundant functions or pathways (Hartman et al., 2001). However, these found in highly dense hubs within genetic interaction networks and perform most of the basic cellular functions (Jeong et al., 2001). Furthermore, essential genes tend to be more highly conserved in evolution; $38 \%$ of essential yeast proteins have easily identifiable counterparts in humans, versus $20 \%$ for nonessential genes (Hughes, 2002). In Drosophila melanogaster temperature-sensitive expression gene vestigial $(\mathrm{vg})$ is altered as it is a key factor in wing development. This temperature-sensitivity of $\mathrm{vg}$ found buffered in populations from temperate climates.

\section{Behavioral Biomarkers}

Altered environmental conditions force animals to change their territory temporarily. The main purpose of migration is to find food and search favorable living conditions and breeding grounds. Migration in animals is influenced by 
weather changes; it creates seasonal to perennial bottlenecks in migrants mainly long distance migratory birds (Chown et al., 2010). It generates slow adaptations according to climate change but larger variations in temperature remains intolerable because these severely affect body physiology in animals (Both et al., 2006; Brommer, 2004). Local variations in weather conditions influence incubation behavior in passerine birds (Coe et al., 2015) and in great tits (Schöll et al., 2019; Seebacher \& Post, 2015). Thus climate induced changes are rectified during migration stay period and animals acquire new advancements in feeding, reproductive and ecological behavior year after year and passed on this genetic adaptation in to new populations through breeding (Børre et al., 2016; Todd et al., 2011).

Climate change increases competition (Lauchlan et al., 2019) and aggression in animals to their competitors (Xu et al., 2018). It reduces easy dispersal, feeding movements (Jourdan et al., 2019) and destabilizes predator-prey interactions in animals (Daugaard et al., 2019). Temperature increases predator attack rate and reduce prey vulnerability (Pepi et al., 2018). Fluctuation in temperature severely affects reproductive behavior in animals due to mate limitation (McEwan et al., 2019). Thermal extremes effect growth in animals (Nishizaki \& Carrington, 2015) and reduce offspring fitness in a cold-climate mainly in viviparous lizards (Cunningham et al., 2018). It also affects emergence of insect and its interaction with plant because of delay in flowering (Kehrberger et al., 2019). Thermal extremes also affect behavior in snail Littorina saxatilis in microhabitat (Chapperon et al., 2017). Similar effects are also seen in metacercariae-infected ants (Botnevik et al., 2016). Temperature also affects weaning behavior in grassland birds (Zuckerberg et al., 2018) and forced animals to prepare thermal defense (Denny, 2018). Slow warming of terrestrial environment generates mild thermal stress that remains tolerable to animals (Scharf et al., 2016). Similarly, slow warming of ocean water increases thermal maxima in crabs, shrimp and fish (Vinagre et al., 2015). But beyond the physiological range no tolerance is seen in both animals of both habitats (Vinagre et al., 2015).

\section{Human Health as an Overall Marker}

Changing climatic conditions are severely affecting human health mainly due to sudden drastic changes in climate or weather factors. Climatic changes are creating unprecedented health problems which never observed in past. Rising temperature also increase risks of communicable diseases mainly for their re-emergence that may surge as epidemic or may change into pandemic (Wang et al., 2019). These may prove more disastrous for both developing and under developed countries (Lim et al., 2012; GBD, 2015). The major impact of global warming is rising incidences of allergic diseases (Chan et al., 2018) communicable and life style diseases (Mohammadi et al., 2018). Variation in temperature severely imposes cardiac arrhythmias and cardiovascular effects in stressed people (Kim \& Kim, 2017; Liu et al., 2015). Increase in intermediate or reservoir host species 
will support the increase in number of infectious agent (Lunde \& Lindtøørn, 2013). In near future increased weather-related disasters will increase because more environmental alterations are possible. These will make condition more vulnerable and impose sever threats to human health Munich Climate-Insurance Initiative (2013). According to WHO both human and plant communities will be worst hit and more disasters are to be faced by people living in coastal areas, small islands and in mountainous areas (Human Development Reports, 2011; WHO, 2004). All climate induced stresses are becoming cumulative, gradual and will impose long-term adverse effects on local and global ecology and environment (Epstein, 2002). Intensity of infectious disease and extreme weather events, such as floods, droughts, earthquakes and other disasters will increase manifold (Smith et al., 2014; Jiao et al., 2019).

\section{Conclusion}

For control of ongoing and projected damage to ecosystems and human communities, global warming should keep to a maximum of $2^{\circ} \mathrm{C}$ over pre-industrial levels, more than this level will threaten human health, water supplies and make ecosystems more vulnerable. But it seems true that warming of at least $1^{\circ} \mathrm{C}$ appears unavoidable. Hence, for developing new safe gourds, mitigate atmospheric $\mathrm{CO}_{2}$ emissions by growing more forests. This is only way to minimize adverse episodic changes in atmosphere and their impact on human health. The more suggestible point is to immediately check combustion of fossil fuels such as coal, oil and natural gas. There must be green life line for green production, green eatables, and green affairs to strengthen world economy and assure its sustainability. Ecological modeling, farm track engineering, urban forestry could play an important role in finding solutions to air pollution soil, erosion control, and noise. Technological development is being required to manage industrial wastes, emissions and waste water treatment for environmental safety. For finding quick solutions more active, visionary and environment favorable political leadership is being required. Both local and national governments should cooperate to manage crop production, price rise and storage with solutions for weather-related risks mainly making society, administration and government pro-active to a disaster response. Government implement long term project plans for rain water harvesting, watershed management, afforestation, green manures, herbal pesticides, and use green technology and increase green energy and production. By making environment safety based policies, development planning establishing control-warning centers can reduce vulnerability to disasters caused due to climate change. Lastly, to increase sustainability of ecosystem and environment Kyoto Protocol norms must be followed by states to combat global warming. Furthermore, prompt action policies, action plans and budgetary provisions are being made to reduce the impact of climate induced effects and mitigation of $\mathrm{CO}_{2}$ emissions. Therefore, major climate induced stresses are to be neutralized by implementing IPCC findings on climate change. Organizations responsible for the assessment and management of health risks become more proactive and 
consider the implications of GCC for their procedures and processes.

\section{Acknowledgements}

I thank HOD department of Zoology, Deen Dayal Upadhyay Gorakhpur University, Gorakhpur for facilities and Prof. S. K. Srivastava for discussions.

\section{Conflicts of Interest}

The author declares no conflicts of interest regarding the publication of this paper.

\section{References}

(2009). Agriculture \& Climate Change-Draft 21.

(2018). Deforestation and Climate Change. Greenpeace.

Adger, W. N. (2006). Vulnerability. Global Environmental Change, 16, 268-281. https://doi.org/10.1016/i.gloenvcha.2006.02.006

Ainsworth, E. A., \& Long, S. P. (2005). What Have We Learned from 15 Years of Free-Air $\mathrm{CO}_{2}$ Enrichment (FACE)? A Meta-Analysis of the Responses of Photosynthesis, Canopy Properties and Plant Production to Rising $\mathrm{CO}_{2}$. New Phytologist, 165, 351-372. https://doi.org/10.1111/j.1469-8137.2004.01224.x

Amininasab, S. M., Kingma, S. A., Birker, M., Hildenbrandt, H., \& Komdeur, J. (2016). The Effect of Ambient Temperature, Habitat Quality and Individual Age on Incubation Behaviour and Incubation Feeding in a Socially Monogamous Songbird. Behavioral Ecology and Sociobiology, 70, 1591-1600. https://doi.org/10.1007/s00265-016-2167-2

Anup (2019). Loss of Biodiversity and Extinctions. Global Issues.

Bajracharya, Mool, \& Shrestha (2009). Glaciers, Glacial Lakes and Glacial Lake Outburst Floods in the Mount Everest Region, Nepal. Annals of Glaciology, 50, 81-86. https://doi.org/10.3189/172756410790595895

Barth, C., Villringer, A., \& Sacher, J. (2015). Sex Hormones Affect Neurotransmitters and Shape the Adult Female Brain during Hormonal Transition Periods. Frontiers in Neuroscience, 9, 37. https://doi.org/10.3389/fnins.2015.00037

Bässler, C., Müller, J., Hothorn, T., Kneib, T., Badeck, F., \& Dziock, F. (2010). Estimation of the Extinction Risk for High-Montane Species as a Consequence of Global Warming and Assessment of Their Suitability as Cross-Taxon Indicators. Ecological Indicators, 10, 341-352. https://doi.org/10.1016/j.ecolind.2009.06.014

Bates, B. C., Kundzewicz, Z. W., Wu, S., \& Palutikof, J. P. (2008). Climate Change and Water (210 p.). Geneva: Technical Paper of the Intergovernmental Panel on Climate Change, IPCC Secretariat.

Ben-Aroya, S., Coombes, C., Kwok, T., O’Donnell, K. A., Boeke, J. D., \& Hieter, P. (2008). Toward a Comprehensive Temperature-Sensitive Mutant Repository of the Essential Genes of Saccharomyces cerevisiae. Molecular Cell, 30, 248-258.

https://doi.org/10.1016/j.molcel.2008.02.021

Bernard, B., Mandiki, S. N. M., Duchatel, V., Rollin, X., \& Kestemont, P. (2019). A Temperature Shift on the Migratory Route Similarly Impairs Hypo-Osmoregulatory Capacities in Two Strains of Atlantic Salmon (Salmo salar L.) Smolts. Fish Physiology and Biochemistry, 45, 1245-1260. https://doi.org/10.1007/s10695-019-00666-x

Bernard, B., Sobandi, K. C., Darras, V., Rollin, X., Mandiki, S. N. M., \& Kestemont, P. 
(2018). Influence of Strain Origin on Osmoregulatory and Endocrine Parameters of Two Non-Native Strains of Atlantic Salmon (Salmo salar L.). General and Comparative Endocrinology, 258, 205-212. https://doi.org/10.1016/j.ygcen.2018.01.004

Both, C., Bouwhuis, S., Lessells, C. M., \& Visser, M. E. (2006). Climate Change and Population Declines in a Long-Distance Migratory Bird. Nature, 441, 81-83.

https://doi.org/10.1038/nature04539

Botnevik, C. F., Malagocka, J., Jensen, A. B., \& Fredensborg, B. L. (2016). Relative Effects of Temperature, Light, and Humidity on Clinging Behavior of Metacercariae-Infected Ants. Journal of Parasitology, 102, 495-500. https://doi.org/10.1645/16-53

Breman, H. (1992). Resource Availability and Tropical Ecosystems. Biotropica OTS Silver Anniversary Symposium. Part B. Special Issue, 24, 328-334.

https://doi.org/10.2307/2388526

Brommer, J. E. (2004). The Range Margins of Northern Birds Shift Polewards. Annales Zoologici Fennici, 41, 391-397.

Butchart, S. H. M., Walpole, M., Collen, B., van Strien, A., Scharlemann, J. P. W., Almond, R. E. A. et al. (2010). Global Biodiversity: Indicators of Recent Declines. Science, 328, 1164-1168. https://doi.org/10.1126/science.1187512

Caissie, D. (2006). The Thermal Regime of Rivers: A Review. Freshwater Biology, 51, 1389-1406. https://doi.org/10.1111/j.1365-2427.2006.01597.x

Cardinale, B. (2014). Overlooked Local Biodiversity Loss (Letter and Response). Science, 344, 1098. https://doi.org/10.1126/science.344.6188.1098-a

Cardinale, B., Duffy, E. J., Duffy, E., Gonzalex, A., Hoper, D. U., Perrings, C. et al. (2012). Biodiversity Loss and Its Impact on Humanity (PDF). Nature, 486, 59-67.

https://doi.org/10.1038/nature11148

Carpenter, K. E., Abrar, M., Aeby, G., Aronson, R. B., Banks, S., Bruckner, A., Chiriboga, A., Cortés, J. et al. (2008). One-Third of Reef-Building Corals Face Elevated Extinction Risk from Climate Change and Local Impacts. Science, 321, 560-563.

https://doi.org/10.1126/science.1159196

Celec, P., Smreková, L., Ostatníková, D., Cabajová, Z., Hodosy, J., \& Kúdela, M. (2009). Lack of Evidence for Meteorological Effects on Infradian Dynamics of Testosterone. International Journal of Biometeorology, 53, 409-413. https://doi.org/10.1007/s00484-009-0225-4

Chadwick, J. G., \& McCormick, S. D. (2017). Upper Thermal Limits of Growth in Brook Trout and Their Relationship to Stress Physiology. Journal of Experimental Biology, 220, 3976-3987. https://doi.org/10.1242/jeb.161224

Chan, A. W., Hon, K. L., Leung, T. F., Ho, M. H., Rosa Duque, J. S., \& Lee, T. H. (2018). The Effects of Global Warming on Allergic Diseases. Hong Kong Medical Journal, 24, 277-284. https://doi.org/10.12809/hkmj177046

Chang, H. H., Cohen, T., Grad, Y. H., Hanage, W. P., O’Brien, T. F., \& Lipsitch, M. (2015). Origin and Proliferation of Multiple-Drug Resistance in Bacterial Pathogens. Microbiology and Molecular Biology Reviews, 79, 101-116. https://doi.org/10.1128/MMBR.00039-14

Chapperon, C., Studerus, K., \& Clavier, J. (2017). Mitigating Thermal Effect of Behaviour and Microhabitat on the Intertidal Snail Littorina saxatilis (Olivi) over Summer. Journal of Thermal Biology, 67, 40-48. https://doi.org/10.1016/j.jtherbio.2017.03.017

Chen, H., Zhang, W. C., Gao, H. R., \& Nie, N. (2018). Climate Change and Anthropogenic Impacts on Wetland and Agriculture in the Songnen and Sanjiang Plain, Northeast China. Remote Sensing, 10, 356. https://doi.org/10.3390/rs10030356 
Chown, S. L., Hoffmann, A. A., Kristensen, T. N., Angilletta Jr., M. J., Stenseth, N. C., \& Pertoldi, C. (2010). Adapting to Climate Change: A Perspective from Evolutionary Physiology. Climate Research, 43, 3-15. https://doi.org/10.3354/cr00879

Christensen, E. A., Svendsen, M. B., \& Steffensen, J. F. (2017). Plasma Osmolality and Oxygen Consumption of Perch Perca fluviatilis in Response to Different Salinities and Temperatures. Journal of Fish Biology, 90, 819-833. https://doi.org/10.1111/jfb.13200

Cochrane, M. A., \& Schulze, M. D. (1999). Fire as a Recurrent Event in Tropical Forests of the Eastern Amazon: Effects on Forest Structure, Biomass, and Species Composition. Biotropica, 31, 2-16. https://doi.org/10.1111/j.1744-7429.1999.tb00112.x

Coe, B. H., Beck, M. L., Chin, S. Y., Jachowski, C. M. B., \& Hopkins, W. A. (2015). Local Variation in Weather Conditions Influences Incubation Behavior and Temperature in a Passerine Bird. Journal of Avian Biology, 46, 385-394.

https://doi.org/10.1111/jav.00581

Colfer, C. J. P., Sheil, D., \& Kishi, M. (2006). Forests and Human Health: Assessing the Evidence. CIFOR Occasional Paper No. 45, Bogor: CIFOR.

Cowan, M., Azpeleta, C., \& López-Olmeda, J. F. (2017). Rhythms in the Endocrine System of Fish: A Review. Journal of Comparative Physiology B, 187, 1057-1089.

https://doi.org/10.1007/s00360-017-1094-5

CSCDGC Center for the Study of Carbon Dioxide and Global Change (2002). Plant Growth Data. http://www.co2science.org./data/plant growth/plantgrowth.php

Cunningham, G. D., Fitzpatrick, L. J., While, G. M., \& Wapstra, E. (2018). Plastic Rates of Development and the Effect of Thermal Extremes on Offspring Fitness in a Cold-Climate Viviparous Lizard. Journal of Experimental Zoology. Part A, Ecological and Integrative Physiology, 329, 262-270. https://doi.org/10.1002/jez.2167

Daugaard, U., Petchey, O. L., \& Pennekamp, F. (2019). Warming Can Destabilize Predator-Prey Interactions by Shifting the Functional Response from Type III to Type II. Journal of Animal Ecology, 88, 1575-1586. https://doi.org/10.1111/1365-2656.13053

Davies, S. J., McGeoch, M. A., \& Clusella-Trullas, S. (2015). Plasticity of Thermal Tolerance and Metabolism but Not Water Loss in an Invasive Reed Frog. Comparative Biochemistry and Physiology-Part A: Molecular \& Integrative Physiology, 189, 11-20. https://doi.org/10.1016/j.cbpa.2015.06.033

De Cochrane, M. A., \& Laurance, W. F. (2002). Fire as a Large-Scale Edge Effect in Amazonian Forests. Journal of Tropical Ecology, 18, 311-325. https://doi.org/10.1017/S0266467402002237

de Leew, J., Waweru, M. N., Okello, O. O., Maloba, M., Nguru, P., Said, M. Y., Aligula, H. M., Heitkonig, I. M. A., \& Reid, R. S. (2001). Distribution and Diversity of Wildlife in Northern Kenya in Relation to Livestock and Permanent Water Points. Biological Conservation, 100, 297-306. https://doi.org/10.1016/S0006-3207(01)00034-9

Denny, M. W. (2018). Survival in Spatially Variable Thermal Environments: Consequences of Induced Thermal Defense. Integrative Zoology, 13, 392-410. https://doi.org/10.1111/1749-4877.12308

Dervo, B. K., Bærum, K. M., Skurdal, J., \& Museth, J. (2016). Effects of Temperature and Precipitation on Breeding Migrations of Amphibian Species in Southeastern Norway. Scientifica, 2016, Article ID: 3174316. https://doi.org/10.1155/2016/3174316

Dube, S. K., Chittibabu, P., Rao, A. D., Sinha, P. C., \& Murty, T. S. (2000). Sea Levels and Coastal Inundation Due to Tropical Cyclones in Indian Coastal Regions of Andhra and Orissa. Marine Geodesy, 23, 65-73. https://doi.org/10.1080/01490410050030643

Ducommun, P., Ruffieux, P., Kadouri, A., von Stockar, U., \& Marison, I. W. (2002). Mon- 
itoring of Temperature Effects on Animal Cell Metabolism in a Packed Bed Process. Biotechnology and Bioengineering, 77, 838-842. https://doi.org/10.1002/bit.10185

Dudgeon, D., Arthington, A. H., Gessner, M. O., Kawabata, Z.-I. et al. (2006). Freshwater Biodiversity: Importance, Threats, Status and Conservation Challenges. Biological Reviews, 81, 163-182. https://doi.org/10.1017/S1464793105006950

DuRant, S. E., Hopkins, W. A., Carter, A. W., Stachowiak, C. M., \& Hepp, G. R. (2013). Incubation Conditions Are More Important in Determining Early Thermoregulatory Ability than Posthatch Resource Conditions in a Precocial Bird Physiological and Biochemical Zoology. Ecological and Evolutionary Approaches, 86, 410-420. https://doi.org/10.1086/671128

Edgar, \& Lielausis (1964). Temperature-Sensitive Mutants of Bacteriophage T4d: Their Isolation and Genetic Characterization. Genetics, 49, 649-662.

Edwards, M., \& Richardson, A. (2004). Impact of Climate Changes on Marine Pelagic Phenology and Trophic Mismatch. Nature, 430, 881-884. https://doi.org/10.1038/nature02808

Ehleringer, J. R., Cerling, T. E., \& Dearing, M. D. (2002). Atmospheric $\mathrm{CO}_{2}$ as a Global Change Driver Influencing Plant-Animal Interactions. Integrative and Comparative Biology, 42, 424-430. https://doi.org/10.1093/icb/42.3.424

Eliasch, J. (2008). Climate Change: Financing Global Forests. The Eliasch Review. London: Earthscan.

Epstein, P. (2002). Climate Change and Infectious Disease: Stormy Weather Ahead? Epidemiology, 13, 373-375. https://doi.org/10.1097/00001648-200207000-00001

Esposito, G., Truzzi, A., Setoh, P., Putnick, D. L., Shinohara, K., \& Bornstein, M. H. (2017). Genetic Predispositions and Parental Bonding Interact to Shape Adults' Physiological Responses to Social Distress. Behavioural Brain Research, 325, 156-162. https://doi.org/10.1016/j.bbr.2016.06.042

Evan, H., DeLucia, P. D., Nabity, J. A. et al. (2012). Climate Change: Resetting Plant-Insect Interactions. Plant Physiology, 160, 1677-1685. https://doi.org/10.1104/pp.112.204750

Fell, S. C., Carrivick, J. L., \& Brown, L. E. (2017). The Multitrophic Effects of Climate Change and Glacier Retreat in Mountain Rivers. BioScience, 67, 897-911. https://doi.org/10.1093/biosci/bix107

Fieber, L. A. (2019). Neurotransmitters and Neuropeptides of Invertebrates. In J. H. Byrne (Ed.), The Oxford Handbook of Invertebrate Neurobiology (pp. 285-301). Oxford: Oxford University Press.

Galatowitsch, S., Frelich, L., \& Phillips-Mao, L. (2009). Regional Climate Change Adaptation Strategies for Biodiversity Conservation in a Midcontinental Region of North America. Biological Conservation, 142, 2012-2022. https://doi.org/10.1016/j.biocon.2009.03.030

Gandiwa, E., \& Kativu, S. (2009). Influence of Fire Frequency on Colophospermum mopane and Combretum apiculatum Woodland Structure and Composition in Northern Gonarezhou National Park, Zimbabwe. Koedoe, 51, Art. 685.

https://doi.org/10.4102/koedoe.v51i1.685

Gandiwa, E., \& Zisadza, P. (2010). Wildlife Management in Gonarezhou National Park, Southeast Zimbabwe: Climate Change and Implications for Management. Nature and Faune, 25, 95-104.

GBD 2015 Risk Factors Collaborators (2015). Global, Regional, and National Comparative Risk Assessment of 79 Behavioral, Environmental and Occupational, and Metabolic Risks or Clusters of Risks, 1990-2015: A Systematic Analysis for the Global Burden of 
Disease Study 2015. The Lancet, 388, 1659-1724.

Geist, H. J., \& Lambin, E. F. (2004). Dynamic Causal Patterns of Desertification. BioScience, 54, 817-829. https://doi.org/10.1641/0006-3568(2004)054[0817:DCPOD]2.0.CO;2

Glantz, M. (1991). The Use of Analogies in Forecasting Ecological and Societal Responses to Global Warming. Environment, 33, 10-33. https://doi.org/10.1080/00139157.1991.9931393

Gonzalez, A., Cardinale, B., Allington, G. R. H., Byrnes, J., Arthur Endsley, K., Brown, D. G., Hooper, D. U., Isbell, F., O'Connor, M. I., \& Loreau, M. (2016). Estimating Local Biodiversity Change: A Critique of Papers Claiming No Net Loss of Local Diversity. Ecology, 97, 1949-1960. https://doi.org/10.1890/15-1759.1

Gottfried, M., Pauli, H., Reiter, K., \& Grabherr, G. (1999). A Fine Scaled Predictive Model for Changes in Species Distribution Patterns of High Mountain Plants Induced by Climate Warming. Diversity and Distributions, 5, 241-251. https://doi.org/10.1046/j.1472-4642.1999.00058.x

Graham, R. S., \& Johnston, I. A. (2012). Temperature during Embryonic Development Has Persistent Effects on Thermal Acclimation Capacity in Zebrafish. PNAS, 109, 1424714252. https://doi.org/10.1073/pnas.1205012109

Grime, J. P., Fridley, J. D., Askew, A. P., Thompson, K., Hodgson, J. G., \& Bennett, C. R. (2008). Long-Term Resistance to Simulated Climate Change in an Infertile Grassland. PNAS, 105, 10028-10032. https://doi.org/10.1073/pnas.0711567105

Gutmann, M., \& Field, V. (2010). Katrina in Historical Context: Environment and Migration in the US. Population and Environment, 31, 3-19. https://doi.org/10.1007/s11111-009-0088-y

Haeberli, W., \& Ambio, M. B. (1998). Climate Change and Its Impacts on Glaciers and Permafrost in the Alps. Ambio, 27, 258-265.

Hallmann, C. A., Sorg, M., Jongejans, E., Siepel, H., Hofland, N., Schwan, H., Stenmans, W., Müller, A., Sumser, H., Hörren, T., Goulson, D., \& de Kroon, H. (2017). More than 75 Percent Decline over 27 Years in Total Flying Insect Biomass in Protected Areas. PLoS ONE, 12, e0185809. https://doi.org/10.1371/journal.pone.0185809

Hanson, C. E. (2007). Impacts, Adaptation and Vulnerability Working Group II Contribution to the Intergovernmental Panel on Climate Change Fourth Assessment Report.

Hartman, J. L., Garvik, B., \& Hartwell, L. (2001). Principles for the Buffering of Genetic Variation. Science, 291, 1001-1004. https://doi.org/10.1126/science.291.5506.1001

Hartwell, L. H., Mortimer, R. K., Culotti, J., \& Culotti, M. (1973). Genetic Control of the Cell Division Cycle in Yeast: V. Genetic Analysis of cdc Mutants, 1967. Genetics, 74, 267-286.

Hays, G. C., Richardson, A. J., \& Robinson, C. (2005). Climate Change and Marine Plankton. Trends in Ecology \& Evolution, 20, 337-344. https://doi.org/10.1016/j.tree.2005.03.004

Helmer, M., \& Hilhorst, D. (2006). Natural Disasters and Climate Change. Disasters, 30, 1-4. https://doi.org/10.1111/j.1467-9523.2006.00302.x

Hemp, S. (2009). Climate Change and Its Impact on the Forests of Kilimanjaro. Journal Compilation, 47, 3-10. https://doi.org/10.1111/j.1365-2028.2008.01043.x

Hinzman, L. D., Bettez, N. D., Bolton, W. R. et al. (2005). Evidence and Implications of Recent Climate Change in Northern Alaska and Other Arctic Regions. Climatic Change, 72, 251-298.

Holzknecht, B. J., Hardardottir, H., Haraldsson, G., Westh, H., Valsdottir, F., Boye, K., 
Karlsson, S., Kristinsson, G., \& Gudlaugsson, O. (2010). Changing Epidemiology of Methicillin-Resistant Staphylococcus aureus in Iceland from 2000 to 2008: A Challenge to Current Guidelines. Journal of Clinical Microbiology, 48, 4221. https://doi.org/10.1128/JCM.01382-10

Hughes, T. R. (2002). Yeast and Drug Discovery. Functional \& Integrative Genomics, 2, 199-211. https://doi.org/10.1007/s10142-002-0059-1

Hulme, M., Barrow, E. M., Arnell, N. W., Harrison, P. A., Johns, T. C., \& Downing, T. A. (1999). Relative Impacts of Human-Induced Climate Change and Natural Climate Variability. Nature, 397, 688-691. https://doi.org/10.1038/17789

Human Development Reports (2011). Sustainability and Equity: A Better Future for All. United Nations Development Programme (UNDP), 1-185. http://hdr.undp.org

Hunter, L. M. (2005). Migration and Environmental Hazards. Population and Environment, 26, 273-302. https://doi.org/10.1007/s11111-005-3343-x

Intergovernmental Panel on Climate Change (IPCC) (1992). The Supplementary Report to the IPCC Scientific Assessment. Cambridge: Cambridge University Press.

International Food Policy Research Institute (2017). Global Nutrition Report 2014: Actions and Accountability to Advance Nutrition and Sustainable Development. https://doi.org/10.2499/9780896298835

IPCC (2019). Special Report on Climate Change, Desertification, Land Degradation, Sustainable Land Management, Food Security, and Greenhouse Gas Fluxes in Terrestrial Ecosystems.

IPCC (Intergovernmental Panel on Climatic Change) (2006). The Economics of Climate Change: Stern Review. The Summary of Conclusions. Survey of the Environment 2007, the Hindu (pp. 141-145).

IUCN/SSC Primate Specialist Group (2008). Endemic Species with Strict Ecological Constraints Are Likely to Be Most Affected.

Jacobsen, D., Milner, A. M., Brown, L. E., \& Dangles, O. (2012). Biodiversity under Threat in Glacier-Fed River Systems. Nature Climate Change, 2, 361-364.

https://doi.org/10.1038/nclimate1435

Jeffries, K. M., Fangue, N. A., \& Connon, R. E. (2018). Multiple Sub-Lethal Thresholds for Cellular Responses to Thermal Stressors in an Estuarine Fish. Comparative Biochemistry and Physiology - Part A: Molecular \& Integrative Physiology, 225, 33-45. https://doi.org/10.1016/j.cbpa.2018.06.020

Jeong, H., Mason, S. P., Barabási, A. L., \& Oltvai, Z. N. (2001). Lethality and Centrality in Protein Networks. Nature, 411, 41-42. https://doi.org/10.1038/35075138

Jiao, S., Chen, W. M., \& Wei, G. H. (2019). Resilience and Assemblage of Soil Microbiome in Response to Chemical Contamination Combined with Plant Growth. Applied and Environmental Microbiology, 85, e02523-18.

https://doi.org/10.1128/AEM.02523-18

Jiao, S., Xu, Y., Zhang, J., Hao, X., \& Lu, Y. (2019). Core Microbiota in Agricultural Soils and Their Potential Associations with Nutrient Cycling. mSystems, 4, e00313-18. https://doi.org/10.1128/mSystems.00313-18

Jourdan, J., Baranov, V., Wagner, R., Plath, M., \& Haase, P. (2019). Elevated Temperatures Translate into Reduced Dispersal Abilities in a Natural Population of an Aquatic Insect. Journal of Animal Ecology, 88, 1498-1509.

https://doi.org/10.1111/1365-2656.13054

Kaushal, S. S., Likens, G. E., Jaworski, N. A., Pace, M. L., Sides, A. M., Seekell, D., Belt, K. T., Secor, D. H., \& Wingate, R. L. (2010). Rising Stream and River Temperatures in the 
United States. Frontiers in Ecology and the Environment, 8, 461-466. https://doi.org/10.1890/090037

Kehrberger, S., Holzschuh, A., Kehrberger, S., \& Holzschuh, A. (2019). Warmer Temperatures Advance Flowering in a Spring Plant More Strongly than Emergence of Two Solitary Spring Bee Species. PLoS ONE, 14, e0218824.

https://doi.org/10.1371/journal.pone.0218824

Kim, J., \& Kim, H. (2017). Influence of Ambient Temperature and Diurnal Temperature Range on Incidence of Cardiac Arrhythmias. International Journal of Biometeorology, 61, 407-416. https://doi.org/10.1007/s00484-016-1221-0

Kucharczyk, D., Luczynski, M., Kujawa, R. et al. (1997). Effect of Temperature on Embryonic and Larval Development of Bream (Abramis brama L.). Aquatic Science, 59, 214-224. https://doi.org/10.1007/BF02523274

Lammertyn, J., Franck, C., Verlinden, B. E., \& Nicolaï, B. M. (2001). Comparative Study of the $\mathrm{O}_{2}, \mathrm{CO}_{2}$ and Temperature Effect on Respiration between "Conference" Pear Cell Protoplasts in Suspension and Intact Pears. Journal of Experimental Botany, 52, 17691777. https://doi.org/10.1093/jexbot/52.362.1769

Landsea, C. (2007). Subject: D3-Why Do Tropical Cyclones' Winds Rotate Counter-Clockwise (Clockwise) in the Northern (Southern) Hemisphere? National Hurricane Center.

Lauchlan, S. S., Burckard, G., Cassey, P., \& Nagelkerken, I. (2019). Climate Change Erodes Competitive Hierarchies among Native, Alien and Range-Extending Crabs. Marine Environmental Research, 151, Article ID: 104777. https://doi.org/10.1016/j.marenvres.2019.104777

Lim, S. S., Vos, T., Flaxman, A. D. et al. (2012). A Comparative Risk Assessment of Burden of Disease and Injury Attributable to 67 Risk Factors and Risk Factor Clusters in 21 Regions, 1990-2010: A Systematic Analysis for the Global Burden of Disease Study 2010. The Lancet, 380, 2224-2260.

Liu, C., Yavar, Z., \& Sun, Q. (2015). Cardiovascular Response to Thermoregulatory Challenges. American Journal of Physiology: Heart and Circulatory Physiology, 309, H1793H1812. https://doi.org/10.1152/ajpheart.00199.2015

Lunde, T. M., \& Lindtjørn, B. (2013). Cattle and Climate in Africa: How Climate Variability Has Influenced National Cattle Holdings from 1961-2008. Peer J, 1, e55. https://doi.org/10.7717/peerj.55

Magnoni, L. J., Eding, E., Leguen, I., Prunet, P., Geurden, I., Ozório, R. O. A., \& Schrama, J. W. (2018). Hypoxia, But Not an Electrolyte-Imbalanced Diet, Reduces Feed Intake, Growth and Oxygen Consumption in Rainbow Trout (Oncorhynchus mykiss). Scientific Reports, 8, Article No. 4965. https://doi.org/10.1038/s41598-018-23352-Z

Malhi, Y., Roberts, J. T., Betts, R. A., Killeen, T. J., Li, W., \& Nobre, C. A. (2008). Climate Change, Deforestation, and the Fate of the Amazon. Science, 319, 169-172. https://doi.org/10.1126/science.1146961

Masroor, W., Farcy, E., Gros, R., \& Lorin-Nebel, C. (2018). Effect of Combined Stress (Salinity and Temperature) in European Sea Bass Dicentrarchus labrax Osmoregulatory Processes. Comparative Biochemistry and Physiology-Part A: Molecular \& Integrative Physiology, 215, 45-54. https://doi.org/10.1016/j.cbpa.2017.10.019

Matysioková, B., \& Remeš, V. (2018). Evolution of Parental Activity at the Nest Is Shaped by the Risk of Nest Predation and Ambient Temperature across Bird Species. Evolution, 72, 2214-2224. https://doi.org/10.1111/evo.13580

McCain, C. M., \& Colwell, R. K. (2011). Assessing the Threat to Montane Biodiversity from Discordant Shifts in Temperature and Precipitation in a Changing Climate. Ecology 
Letters, 14, 1236-1245. https://doi.org/10.1111/j.1461-0248.2011.01695.x

McEwan, G. F., Groner, M. L., Cohen, A. A. B., Imsland, A. K. D., \& Revie, C. W. (2019). Modelling Sea Lice Control by Lumpfish on Atlantic Salmon Farms: Interactions with Mate Limitation, Temperature and Treatment Rules. Diseases of Aquatic Organisms, 133, 69-82. https://doi.org/10.3354/dao03329

McGeoch, M. A., Butchart, S. H. M., Spear, D., Marais, E., Kleynhans, E. J., Symes, A., Chanson, J., \& Hoffmann, M. (2010). Global Indicators of Biological Invasion: Species Numbers, Biodiversity Impact and Policy Responses. Diversity and Distributions, 16, 95-108. https://doi.org/10.1111/j.1472-4642.2009.00633.x

McLeman, R. A., \& Smit, B. (2006). Migration as an Adaptation to Climate Change. Climatic Change, 76, 31-53. https://doi.org/10.1007/s10584-005-9000-7

Meze-Hausken, E. (2000). Migration Caused by Climate Change: How Vulnerable Are People in Dryland Areas? Mitigation Adaptation Strategies Global Change, 5, 379-406. https://doi.org/10.1023/A:1026570529614

Mohammadi, R., Soori, H., Alipour, A., Bitaraf, E., \& Khodakarim, S. (2018). The Impact of Ambient Temperature on Acute Myocardial Infarction Admissions, in Tehran, Iran. Journal of Thermal Biology, 73, 24-31. https://doi.org/10.1016/j.jtherbio.2018.02.008

Mormede, P., \& Terenina, E. (2012). Molecular Genetics of the Adrenocortical Axis and Breeding for Robustness. Domestic Animal Endocrinology, 43, 116-131. https://doi.org/10.1016/j.domaniend.2012.05.002

Mueller, A. J., Miller, D., \& Bowers, E. K. (2019). Nest Microclimate during Incubation Affects Posthatching Development and Parental Care in Wild Birds. Scientific Reports, 9, Article No. 5161. https://doi.org/10.1038/s41598-019-41690-4

Munich Climate-Insurance Initiative (2013). Climate Change and Rising Weather Related Disasters.

Nelson, G. C., Bennett, E., Berhe, A. A., Cassman, K., DeFries, R., Dietz, T., Dobermann, A., Dobson, A., Janetos, A., Levy, M., Marco, D., Nakicenovic, N., O’Neill, B., Norgaard, R., Petschel-Held, G., Ojima, D., Pingali, P., Watson, R., \& Zurek, M. (2006). Anthropogenic Drivers of Ecosystem Change: An Overview. Ecology and Society, 11, 29. https://doi.org/10.5751/ES-01826-110229

Nishizaki, M. T., \& Carrington, E. (2015). The Effect of Water Temperature and Velocity on Barnacle Growth: Quantifying the Impact of Multiple Environmental Stressors. Journal of Thermal Biology, 54, 37-46. https://doi.org/10.1016/j.jtherbio.2015.02.002

North American Bird Conservation Initiative and US Committee (2010).

Öberg, M., Arlt, D., Pärt, T., Laugen, A. T., Eggers, S., \& Low, M. (2015). Rainfall during Parental Care Reduces Reproductive and Survival Components of Fitness in a Passerine Bird. Ecology and Evolution, 5, 345-356. https://doi.org/10.1002/ece3.1345

Ott, J. (2010). The Big Trek Northwards: Recent Changes in the European Dragonfly Fauna. In J. Settele, L. Penev, T. Georgiev, R. Grabaum, V. Grobelnik, V. Hammen, S. Klotz, M. Kotarac, \& I. Kühn (Eds.), Atlas of Biodiversity Risk (p. 280). Sofia: Pensoft.

Parry, M. L., Canziani, O. F., Palutikof, J. P., \& Parry, M. L. (2007a). Climate Change 2007: Impacts, Adaptation and Vulnerability.

Parry, M. L., Canziani, O. F., Palutikof, J. P., van der Linden, P. J., \& Hanson, C. E. (2007b). Human Health Climate Change 2007: Impacts, Adaptation and Vulnerability. Contribution of Working Group II to the Fourth Assessment Report of the Intergovernmental Panel on Climate Change (pp. 391-431). Cambridge: Cambridge University Press.

Pauli, H., Gottfried, M., Hohenwallner, D., Reiter, K., \& Grabherr, G. (2005). Ecological 
Climate Impact Research in High Mountain Environments: GLORIA (Global Observation Research Initiative in Alpine Environments) Its Roots, Purpose and Long-Term Perspectives. In U. M. Huber, H. K. M. Bugmann, \& M. A. Reasoner (Eds.), Global Change and Mountain Regions (pp. 383-391). Advances in Global Change Research Vol. 23, Dordrecht: Springer. https://doi.org/10.1007/1-4020-3508-X 38

Peel, M. C., Finlayson, B. L., \& McMahon, T. A. (2007). Updated World Map of the Köppen-Geiger Climate Classification. Hydrology and Earth System Sciences, 11, 16331644. https://doi.org/10.5194/hess-11-1633-2007

Pennisi, E. (2019). Common Pesticide Makes Migrating Birds Anorexic. Science. https://doi.org/10.1126/science.aaz4736

Pepi, A., Grof-Tisza, P., Holyoak, M., \& Karban, R. (2018). As Temperature Increases, Predator Attack Rate Is More Important to Survival than a Smaller Window of Prey Vulnerability. Ecology, 99, 1584-1590. https://doi.org/10.1002/ecy.2356

Perch-Nielsen, S., Bättig, M., \& Imboden, D. (2008). Exploring the Link between Climate Change and Migration. Climatic Change, 91, 375-393. https://doi.org/10.1007/s10584-008-9416-y

Poff, N. L., Allan, J. D., Bain, M. B., Karr, J. R., Prestegaard, K. L., Richter, B. D., Sparks, R. E., \& Stromberg, J. C. (1997). The Natural Flow Regime: A Paradigm for River Conservation and Restoration. Bioscience, 47, 769-784. https://doi.org/10.2307/1313099

Popoli, M., Yan, Z., McEwen, B., \& Sanacora, G. (2011). The Stressed Synapse: The Impact of Stress and Glucocorticoids on Glutamate Transmission. Nature Reviews Neuroscience, 13, 22-37. https://doi.org/10.1038/nrn3138

Rafferty, J. P., \& Pimm, S. L. (2019). Desertification Ecology. In Encyclopædia Britannica. Scotland: Encyclopedia Britannica Inc.

Rahman, A. (2016). Impact of Human Activities on Wetland: A Case Study from Bongaigaon District, Assam, India. International Journal of Current Microbiology and Applied Sciences, 5, 392-396. https://doi.org/10.20546/ijcmas.2016.503.046

Rasler, K., \& Thompson, W. R. (1985). War and the Economic Growth of Major Powers. American Journal of Political Science, 29, 513-538. https://doi.org/10.2307/2111141

Rates of Deforestation \& Reforestation in the U.S.

Reyjol, Y., Hugueny, B., Pont, D., Bianco, P. G., Beier, U., Caiola, N., Casals, F., Cowx, I. G., Economou, A., Ferreira, M. T., Haidvogl, G., Noble, R., de Sostoa, A., Vigneron, T., \& Virbickas, T. (2007). Patterns in Species Richness and Endemism of European Freshwater Fish. Global Ecology and Biogeography, 16, 65-75. https://doi.org/10.1111/j.1466-8238.2006.00264.x

Riedo, M., Gyalistras, D., \& Fuhrer, J. (2001). Pasture Responses to Elevated Temperature and Doubled $\mathrm{CO}_{2}$ Concentration: Assessing the Spatial Pattern across an Alpine Landscape. Climate Research, 17, 19-31. https://doi.org/10.3354/cr017019

Rosenzweig, C., \& Hillel, D. (1993). The Dust Bowl of the 1930s: Analog of Greenhouse Effect in the Great Plains? Journal of Environmental Quality, 22, 9-22. https://doi.org/10.2134/jeq1993.00472425002200010002x

Saboureau, M., Bobet, J. P., \& Boissin, J. (1980). Cyclic Activity of Adrenal Function and Seasonal Variations of Cortisol Peripheral Metabolism in a Hibernating Mammal, the Hedgehog (Erinaceus europaeus L.). Journal of Physiology (Paris), 76, 617-629.

Scharf, I., Wexler, Y., MacMillan, H. A., Presman, S., Simson, E., \& Rosenstein, S. (2016). The Negative Effect of Starvation and the Positive Effect of Mild Thermal Stress on Thermal Tolerance of the Red Flour Beetle, Tribolium castaneum. Naturwissenschaften, 103, 20. https://doi.org/10.1007/s00114-016-1344-5 
Schöll, E. M. et al. (2019). Diurnal Patterns of Ambient Temperature But Not Precipitation Influence Incubation Behavior in Great Tits. Journal of Ornithology, 161, 529-538. https://doi.org/10.1007/s10336-019-01737-9

Schulte, P. M. (2015). The Effects of Temperature on Aerobic Metabolism: Towards a Mechanistic Understanding of the Responses of Ectotherms to a Changing Environment. Journal of Experimental Biology, 218, 1856-1866. https://doi.org/10.1242/jeb.118851

Seebacher, F., \& Post, E. (2015). Climate Changes Impacts on Animal Migration. Climate Change Responses, 2, Article No. 5. https://doi.org/10.1186/s40665-015-0013-9

Shaughnessy, C. A., \& McCormick, S. D. (2018). Reduced Thermal Tolerance during Salinity Acclimation in Brook Trout (Salvelinus fontinalis) Can Be Rescued by Prior Treatment with Cortisol. Journal of Experimental Biology, 221, pii: jeb169557.

https://doi.org/10.1242/jeb.169557

Shukla, J., Nobre, C., \& Sellers, P. (1990). Amazon Deforestation and Climate Change. Science, 247, 1322-1325. https://doi.org/10.1126/science.247.4948.1322

Sievers, M., Hale, R., Parris, K. M., \& Swearer, S. E. (2018). Impacts of Human-Induced Environmental Change in Wetlands on Aquatic Animals. Biological Reviews of the Cambridge Philosophical Society, 93, 529-554. https://doi.org/10.1111/brv.12358

Smit, B., \& Wandel, J. (2006). Adaptation, Adaptive Capacity and Vulnerability. Global Environmental Change, 16, 282-292. https://doi.org/10.1016/j.gloenvcha.2006.03.008

Smith, K. R., Woodward, A., Campbell-Lendrum, D., Chadee, D. D., Honda, Y., Liu, Q., Olwoch, J. M., Revich, B., \& Sauerborn, R. (2014). Human Health: Impacts, Adaptation, and Co-Benefits. In C. B. Field (Ed.), Climate Change 2014: Impacts, Adaptation, and Vulnerability. Part A: Global and Sectoral Aspects. Contribution of Working Group II to the Fifth Assessment Report of the Intergovernmental Panel on Climate Change (pp. 709-754). Cambridge and New York: Cambridge University Press.

Smith, L. C. (2000). Trends in Russian Arctic River-Ice Formation and Breakup, 1917 to 1994. Physical Geography, 21, 46-56. https://doi.org/10.1080/02723646.2000.10642698

Stacey, D. A., \& Fellows, M. D. E. (2002). Influence of Elevated $\mathrm{CO}_{2}$ on Interspecific Interactions at Higher Trophic Levels. Global Change Biology, 8, 668-678.

https://doi.org/10.1046/j.1365-2486.2002.00506.x

Sur, S., Sharma, A., Trivedi, A. K., Bhardwaj, S. K., \& Kumar, V. (2019). Temperature Affects Liver and Muscle Metabolism in Photostimulated Migratory Redheaded Buntings (Emberiza bruniceps). Journal of Comparative Physiology B, 189, 623-635. https://doi.org/10.1007/s00360-019-01229-5

Tacoli, C. (2009). Crisis or Adaptation? Migration and Climate Change in a Context of High Mobility. Environment and Urbanization, 21, 513-525. https://doi.org/10.1177/0956247809342182

Todd, B. D., Scott, D. E., Pechmann, J. H. K., \& Whitfield Gibbons, J. (2011). Climate Change Correlates with Rapid Delays and Advancements in Reproductive Timing in an Amphibian Community. Proceedings of the Royal Society B: Biological Sciences, 278, 2191-2197. https://doi.org/10.1098/rspb.2010.1768

Tomotani, B. M., van der Jeugd, H., Gienapp, P., de la Hera, I., Pilzecker, J., Teichmann, C., \& Visser, M. E. (2018). Climate Change Leads to Differential Shifts in the Timing of Annual Cycle Stages in a Migratory Bird. Global Change Biology, 24, 823-835. https://doi.org/10.1111/gcb.14006

van den Bosch, M., \& Meyer-Lindenberg, A. (2019). Environmental Exposures and Depression: Biological Mechanisms and Epidemiological Evidence. Annual Review of 
Public Health, 40, 239-259. https://doi.org/10.1146/annurev-publhealth-040218-044106

Veteli, T. O., Kuokkanen, K., Julkunen-Tiitto, R., Roininen, H., \& Tahvanainen, J. (2002). Effects of Elevated $\mathrm{CO}_{2}$ and Temperature on Plant Growth and Herbivore Defensive Chemistry. Global Change Biology, 8, 1240-1252. https://doi.org/10.1046/j.1365-2486.2002.00553.x

Vinagre, C., Leal, I., Mendonça, V., \& Flores, A. A. (2015). Effect of Warming Rate on the Critical Thermal Maxima of Crabs, Shrimp and Fish. Journal of Thermal Biology, 47, 19-25. https://doi.org/10.1016/j.jtherbio.2014.10.012

Visser, M. E., \& Both, C. (2005). Shifts in Phenology Due to Global Climate Change: The Need for a Yardstick. Proceedings of the Royal Society B: Biological Sciences, 272, 2561-2569.

Walsh, J. R., Carpenter, S. R., \& Vander Zanden, M. J. (2016). Invasive Species Triggers a Massive Loss of Ecosystem Services through a Trophic Cascade. Proceedings of the National Academy of Sciences of the United States of America, 13, 4081-4085. https://doi.org/10.1073/pnas.1600366113

Wang, H. T., Liu, Z. D., Lao, J. H., Zhao, Z., \& Jiang, B. F. (2019). Lag Effect and Influencing Factors of Temperature on Other Infectious Diarrhea in Zhejiang Province. Chinese Journal of Epidemiology, 40, 960-964.

Webb, P., Stordalen, G. A., Singh, S., Wijesinha-Bettoni, R., Shetty, P., \& Lartey, A. (2018). Hunger and Malnutrition in the 21st Century. BMJ, 361, k2238. https://doi.org/10.1136/bmj.k2238

Westerling, A. L., Hidalgo, H. G., Cayan, D. R., \& Swetnam, T. W. (2006). Warming and Earlier Spring Increase Western U.S. Forest Wildfire Activity. Science, 313, 940-943. https://doi.org/10.1126/science.1128834

Whitmore, T. C. (1990). An Introduction to Tropical Rain Forests. Hoboken, NJ: John Wiley \& Sons Ltd. https://doi.org/10.1111/j.1756-1051.1991.tb01264.x

WHO (2004). The Global Burden of Disease: 2004 Update. https://www.who.int/healthinfo/global burden disease/en/

Wilby, R. L., \& Harris, I. (2006). A Framework for Assessing Uncertainties in Climate Change Impacts: Low Flow Scenarios for the River Thames. Water Resources Research, 42, W02419. https://doi.org/10.1029/2005WR004065

Wilkinson, C. (2004). Statusofcoral Reefsofthe World.

Willetts, E., Guadagno, L., \& Ikkala, N. (2010). Addressing Climate Change, Issues and Solutions from around the World (40 p.). Gland: IUCN.

Woodward, G., Perkins, D. M., \& Brown, L. E. (2010). Climate Change and Freshwater Ecosystems: Impacts across Multiple Levels of Organization. Philosophical Transactions of the Royal Society of London. Series B, Biological Sciences, 365, 2093-2106. https://doi.org/10.1098/rstb.2010.0055

Working Group III Technical Support Unitc/o Imperial College.

World Wildlife Funds (WWF) (2011). World Wildlife Fund's 50th Anniversary Year World Wildlife Fund. Washington DC. https://www.worldwildlife.org/

Xu, X. M., Chi, Q. S., Cao, J., \& Zhao, Z. J. (2018). The Effect of Aggression I: The Increases of Metabolic Cost and Mobilization of Fat Reserves in Male Striped Hamsters. Hormones and Behavior, 98, 55-62. https://doi.org/10.1016/j.yhbeh.2017.12.015

Youssef, A., Exadaktylos, V., \& Berckmans, D. (2014). Modelling and Quantification of the Thermoregulatory Responses of the Developing Avian Embryo: Electrical Analogies of a Physiological System. Journal of Thermal Biology, 44, 14-19.

https://doi.org/10.1016/j.jtherbio.2014.05.006 
Zaime, A., Laraki, M., Gautier, J. Y., \& Garnier, D. H. (1992). Seasonal Variations of Androgens and of Several Sexual Parameters in Male Meriones Shawi in Southern Morocco. General and Comparative Endocrinology, 86, 289-296.

https://doi.org/10.1016/0016-6480(92)90113-X

Zeng, N., \& Yoon, J. (2009). Expansion of the World's Deserts Due to Vegetation-Albedo Feedback under Global Warming. Geophysical Research Letters, 36, 17. https://doi.org/10.1029/2009GL039699

Zuckerberg, B., Ribic, C. A., \& McCauley, L. A. (2018). Effects of Temperature and Precipitation on Grassland Bird Nesting Success as Mediated by Patch Size. Conservation Biology, 32, 872-882. https://doi.org/10.1111/cobi.13089 